AL.2.2.2003-310

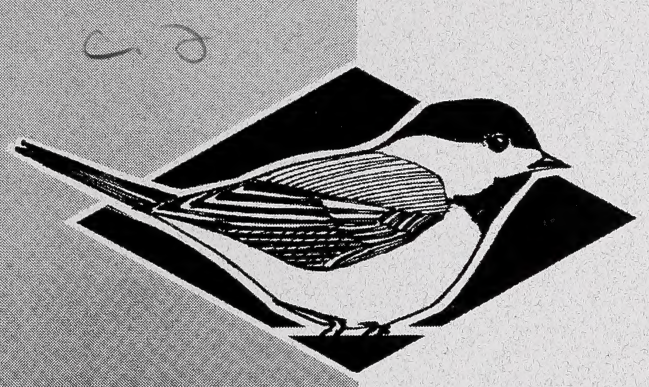

\section{Fish \& Wildife} Division

RESOURCE STATUS AND ASSESSMENT BRANCH

\title{
Status of the Banff Springs Snail (Physella johnsoni) in Alberta
}

\author{
Dwayne A. W. Lepitzki
}

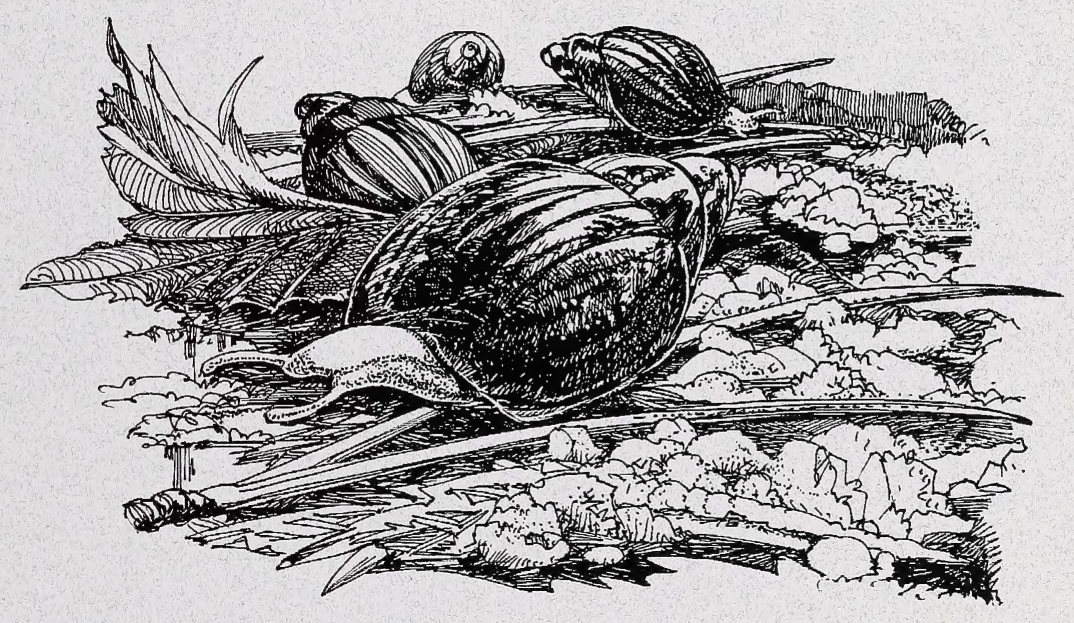

Alberta Wildlife Status Report No. 40

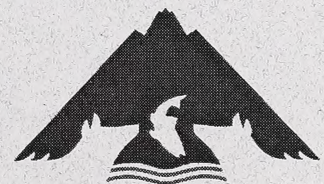

Alberta Conservation Association 


\title{
Status of the Banff Springs Snail (Physella johnsoni) in Alberta
}

\author{
Dwayne A.W. Lepitzki
}

Alberta Wildlife Status Report No. 40

March 2002

Published By:

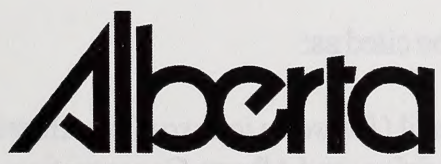

SUSTAINABLE RESOURCE DEVELOPMENT

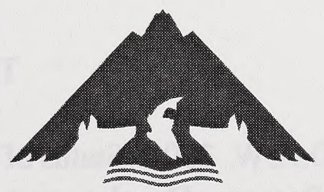

Alberta Conservation Association"

Funded by Alberta Anglers, Hunters, and Other Conservationists 
Publication No. T/015

ISBN: 0-7785-1985-6 (Printed Edition)

ISBN: 0-7785-1986-4 (On-line Edition)

ISSN: 1206-4912 (Printed Edition)

ISSN: 1499-4682 (On-line Edition)

Series Editor: Sherry Feser and Robin Gutsell

Illustrations: Brian Huffman

For copies of this report, contact:

Information Centre - Publications

Alberta Environment/Alberta Sustainable Resource Development

Fish and Wildlife Division

Main Floor, Great West Life Building

9920 - 108 Street

Edmonton, Alberta, Canada T5K 2M4

Telephone: (780) 422-2079

\section{OR}

Information Service

Alberta Environment/Alberta Sustainable Resource Development

$\# 100,3115$ - 12 Street NE

Calgary, Alberta, Canada T2E 7J2

Telephone: (780) 297-3362

\section{OR}

Visit our web site at :

http://www3.gov.ab.ca/srd/fw/status/index.html

This publication may be cited as:

Lepitzki, D.A.W. 2002. Status of the Banff Springs Snail (Physella johnsoni) in Alberta. Alberta Sustainable Resource Development, Fish and Wildlife Division, and Alberta Conservation Association,

Wildlife Status Report No. 40, Edmonton, AB. 29 pp. 


\section{PREFACE}

Every five years, the Fish and Wildlife Division of Alberta Sustainable Resource Development reviews the status of wildlife species in Alberta. These overviews, which have been conducted in 1991, 1996 and 2000, assign individual species "ranks" that reflect the perceived level of risk to populations that occur in the province. Such designations are determined from extensive consultations with professional and amateur biologists, and from a variety of readily available sources of population data. A primary objective of these reviews is to identify species that may be considered for more detailed status determinations.

The Alberta Wildlife Status Report Series is an extension of the general statusing exercises (1996 Status of Alberta Wildlife, The General Status of Alberta Wild Species 2000), and provides comprehensive current summaries of the biological status of selected wildlife species in Alberta. Priority is given to species that are potentially at risk in the province ("At Risk," "May Be At Risk"), that are of uncertain status ("Undetermined"), or those considered to be at risk at a national level by the Committee on the Status of Endangered Wildlife in Canada (COSEWIC).

Reports in this series are published and distributed by the Alberta Conservation Association and the Fish and Wildlife Division of Alberta Sustainable Resource Development. They are intended to provide detailed and up-to-date information which will be useful to resource professionals for managing populations of species and their habitats in the province. The reports are also designed to provide current information which will assist the Alberta Endangered Species Conservation Committee to identify species that may be formally designated as "Endangered" or "Threatened" under Alberta's Wildlife Act. To achieve these goals, the reports have been authored and/or reviewed by individuals with unique local expertise in the biology and management of each species. 


\section{EXECUTIVE SUMMARY}

The Banff springs snail, Physella johnsoni (Clench 1926), is a small, inconspicuous freshwater mollusc endemic to thermal springs near the town of Banff, within Banff National Park, Alberta (Clench 1926, Clarke 1973, 1977, 1981, Lepitzki 1997a,b, 1998, 1999, 2000a). This species has been collected twice since it was originally described in 1926 by Clench; once in 1965 (Clarke 1973) and also in 1975 (Parks Canada 1975). After the 1965 collection, Clarke (1977) suggested that the species was "clearly endangered." Parks Canada subsequently identified P. johnsoni as a special resource and a species that was "vulnerable .... and .... threatened by development" (Achuff et al. 1986). Based on the status report of Lepitzki (1997b) the Committee on the Status of Endangered Wildlife in Canada (COSEWIC) designated the species as "Threatened" in 1997 and then uplisted it to "Endangered" in 2000 (COSEWIC 2000). This was Canada's first extant mollusc to be placed on the Species At Risk list. Physella johnsoni has been ranked "At Risk" in Alberta (Lepitzki 2001). This report summarizes all information on the Banff springs snail as a step in updating its status in the province.

The Banff springs snail research and recovery program began in January 1996, concurrent with the study to determine its status for COSEWIC. The species' distribution, population fluctuations, microdistribution, reproductive biology, and association with water physicochemistry are the main areas of study. Results of this research are contained in annual reports written for Parks Canada (Lepitzki 1997a, 1998, 1999, 2000a) and are summarized in this report.

A draft Resource Management Plan (RMP) for the recovery of the snail has been in place since the summer of 1998; the latest revision (Lepitzki et al. 2001a) is undergoing internal review. Implementing the three prongs of the RMP (science, communications, and protection) in concert will ensure the species' survival; however, continuing provision of time, money, and effort on this unique microfaunal species is necessary to address the public's lack of awareness of invertebrate conservation and the inherent values of biodiversity. 


\section{ACKNOWLEDGEMENTS}

Data and information in this report are derived from the Banff springs snail research and recovery program, which was initiated in 1996. Major funding agencies included Parks Canada and the Endangered Species Recovery Fund, co-sponsored by World Wildlife Fund Canada, the Canadian Wildlife Service of Environment Canada, and the Canadian Millennium Partnership Program. Other funding sources included the Friends of Banff National Park, the Canadian Wildlife Federation (COSEWIC status report), and the Bow Valley Naturalists. People who have been instrumental in this program include Dave Dalman (Ecosystem Secretariate, Banff National Park), Mary Dalman and Christine Aikens (Communication Specialists, Banff National Park Warden Service), Rob Harding, Carolyn Fysh, Marjorie Huculak, and Steve Malins (Cultural Resources and Historic Sites, Banff National Park), Steve Nyilas (Trades, Banff National Park), Dave Hunter, Joanne Cairns, Bill Hunt, and Michael Goon (Banff National Park Wardens), and Charlie Pacas (Aquatics Specialist for Banff, Kootenay, and Yoho National Parks). Charlie has been the driving force ensuring that Parks Canada continues to give the snail the priority it deserves. Brenda Lepitzki has provided excellent field, laboratory, and office assistance. The following people provided personal communication contained within this report: Theresa Aniskowicz-Fowler (COSEWIC), Hebert Athearn (Museum of Fluviatile Mollusks), Adam Baldinger (Harvard University), Arthur Clarke (ECORESEARCH), Stephen Grasby (Geological Survey of Canada), Joseph Nelson (University of Alberta), Wayne Nordstrom (ANHIC), Eva Pip (University of Winnipeg) and Drajs Vujnovic (ANHIC). Dawn Birn, Sherry Feser (Alberta Conservation Association), Robin Gutsell (Alberta Sustainable Resource Development) Jacqueline Lee (Westwater Research), Dr. Eva Pip (University of Winnipeg), Dr. Allen Shostak (University of Alberta), and Arlen Todd (Alberta Sustainable Resource Development) reviewed and made improvements to earlier drafts of this report.

Preparation of this report was funded by the Wildlife Management Enhancement Program of the Alberta Conservation Association and the Fish and Wildlife Division of Alberta Sustainable Resource Development. 
Digitized by the Internet Archive in 2016

https://archive.org/details/statusofbanffspro0lepi_0 


\section{TABLE OF CONTENTS}

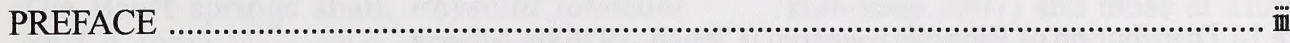

EXECUTIVE SUMMARY ………………………….....................................................

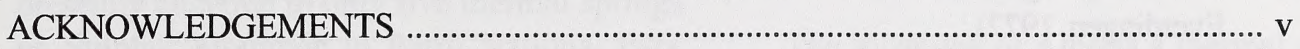

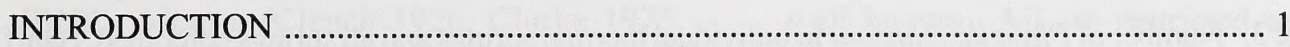

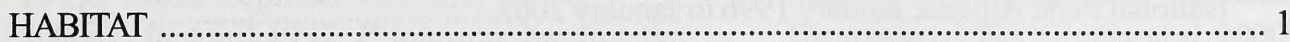

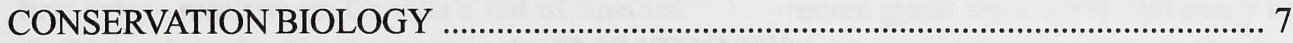

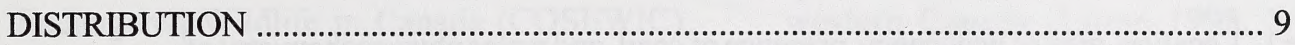

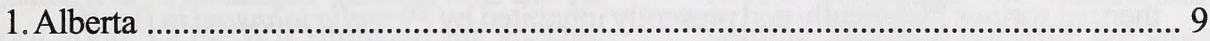

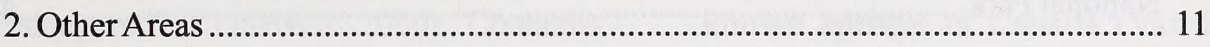

POPULATION SIZE AND TRENDS ..................................................................... 11

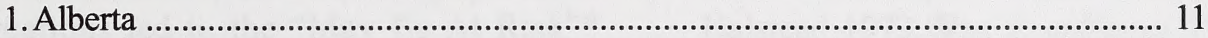

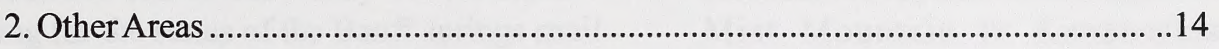

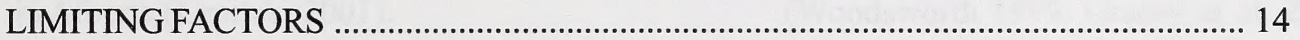

1. Endemicity and Dependence on Rare, Unique, and Fragile Thermal Spring Habitats..14

2. Habitat Loss and Alteration, and Human Disturbance ............................................. 14

3. Water Flow and Climate Change ............................................................................16

4. Natural Mortality Factors .................................................................................... 16

5. Public Attitudes Toward Invertebrates and Invertebrates in Protected Areas ............ 17

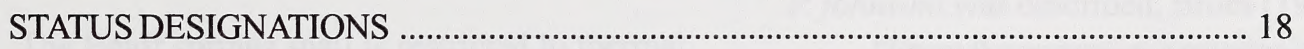

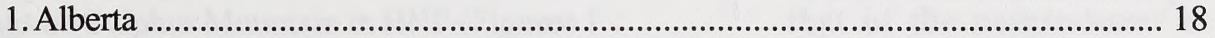

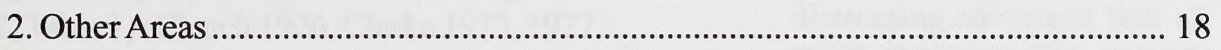

RECENT MANAGEMENT AND RESEARCH IN ALBERTA ……………………......... 18

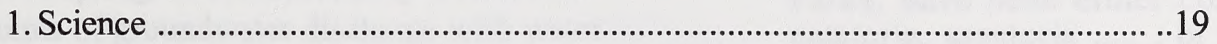

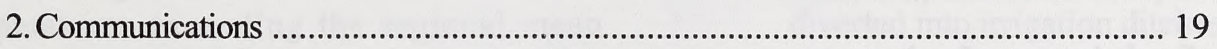

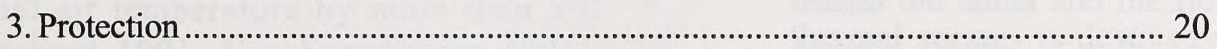

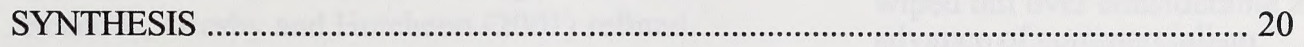

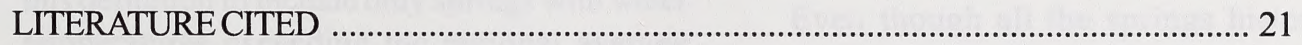

APPENDIX 1 Definitions of selected legal and protective designations. ................................. 28 


\section{LIST OF FIGURES}

Figure 1. Distribution of Physella johnsoni (Clench, 1926) in Alberta.................................. 2

Figure 2. Thermal springs near Banff Townsite, Banff National Park, Alberta (modified from Van Everdingen, 1972). 3

Figure 3. Number of Physella johnsoni in individual thermal springs and all springs combined, Banff National Park, Alberta, January 1996 to January 2002.

\section{LIST OF TABLES}

Table 1. Location, area of occupancy, presence of snail, and water physicochemistry of thermal springs historically and presently inhabited by Physella johnsoni in Banff National Park. 


\section{INTRODUCTION}

The Banff springs snail, Physella johnsoni (Clench 1926), is a small (approximately $5.0 \mathrm{~mm}$ shell length), inconspicuous freshwater snail presently endemic to only five thermal springs on Sulphur Mountain in Banff National Park (BNP), Alberta (Clench 1926, Clarke 1973, 1977, 1981, Lepitzki 1997a,b, 1998, 1999, 2000a). In April 1997, P. johnsoni became the first extant mollusc on Canada's list of Species At Risk when the Committee on the Status of Endangered Wildlife in Canada (COSEWIC) designated it as "Threatened" (COSEWIC 2000). In April 2000, COSEWIC uplisted the species to "Endangered" (COSEWIC 2000). Concerns over its localized distribution, restricted microdistribution, and severe population fluctuations led to the "May Be At Risk"* ranking for the status of the Banff springs snail in Alberta (Lepitzki 2001).

Before 1996, all that was known about this unique species was its historic distribution. This report reviews new information as a step in assessing the status of the species in the province.

\section{HABITAT}

The Banff springs snail is restricted to thermal springs on Sulphur Mountain in BNP (Figures 1 and 2, Table 1) (Clench 1926, Clarke 1973, 1977, 1981, Lepitzki 1997a,b, 1998, 1999, 2000a). Thermal springs have traditionally been defined as points of groundwater discharge with water temperatures exceeding the regional mean annual air temperature by more than $5^{\circ} \mathrm{C}$ (Pritchard 1991, Van Everdingen 1991). Recently, Grasby and Hutcheon (2001) refined this definition to include only springs with water temperatures exceeding the regional average annual air temperature by more than $10^{\circ} \mathrm{C}$ (as a result of low average air and groundwater temperatures in British Columbia and Alberta).

* See Appendix 1 for definitions of selected status designations.
Of the known springs in BNP, only some along the Sulphur Mountain Thrust Fault (Grasby and Hutcheon 2001) and those at Third Vermilion Lake (Bourgeau Thrust Fault, Grasby and Hutcheon 2001) can be considered thermal.

The locations of Alberta's thermal springs are well known. All are restricted to the Rocky Mountains (Souther and Halstead 1973, Van Everdingen 1991, Grasby et al. 2000) and several recent guide books pinpoint every known spring location in the Pacific northwest states and western Canada (Litton 1998, Woodsworth 1999). Although, the sulphurous springs on Sulphur Mountain in BNP are among the bestknown springs in Canada (Van Everdingen 1972), other thermal springs in Alberta are found at Miette in Jasper National Park (Souther and Halstead 1973, Van Everdingen 1991) and at Mist Mountain in Kananaskis Country (Woodsworth 1999, Grasby et al. 2000). It is extremely unlikely that any "undiscovered" thermal spring ecosystems exist.

In North America, if not worldwide, thermal springs are often altered for human use, resulting in loss of ecological integrity (loss of native species and processes). In the same decade that P. johnsoni was described, Brues (1928) stated:

"From the naturalist's standpoint and from that of the nature-lover as well it is distressing to record that all except the most inaccessible springs, or those included within the boundaries of National Parks, have been either converted to natatoria, sanatoria ..... , or have been diverted into irrigation ditches.... For this reason the fauna and the flora of these thermal springs is destined soon to be wiped out over considerable areas by the advance of commercialism."

Even though all the springs historically and presently occupied by P. johnsoni are protected within the boundaries of a national park (Table 1), all have been impacted by humans (see Lepitzki 1997a,b, Lepitzki et al. 2001a). The Upper Hot Spring is the source for the only remaining thermal spring public bathing facility in BNP and has been continually used as such 


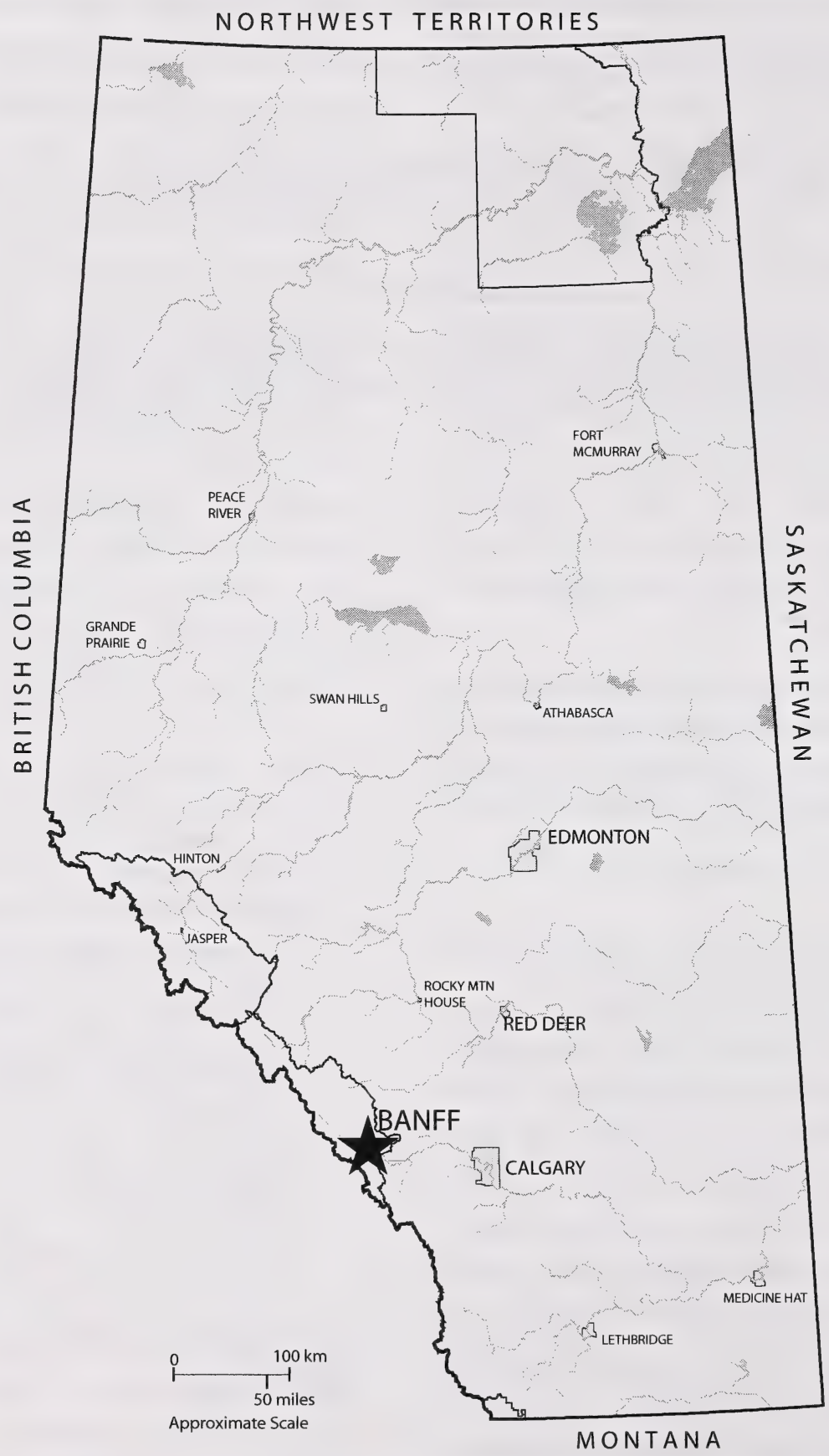

Figure 1. Distribution of Physella johnsoni (Clench, 1926) in Alberta. The star denotes the historic and present distribution. 


\section{Vermilion Lakes}

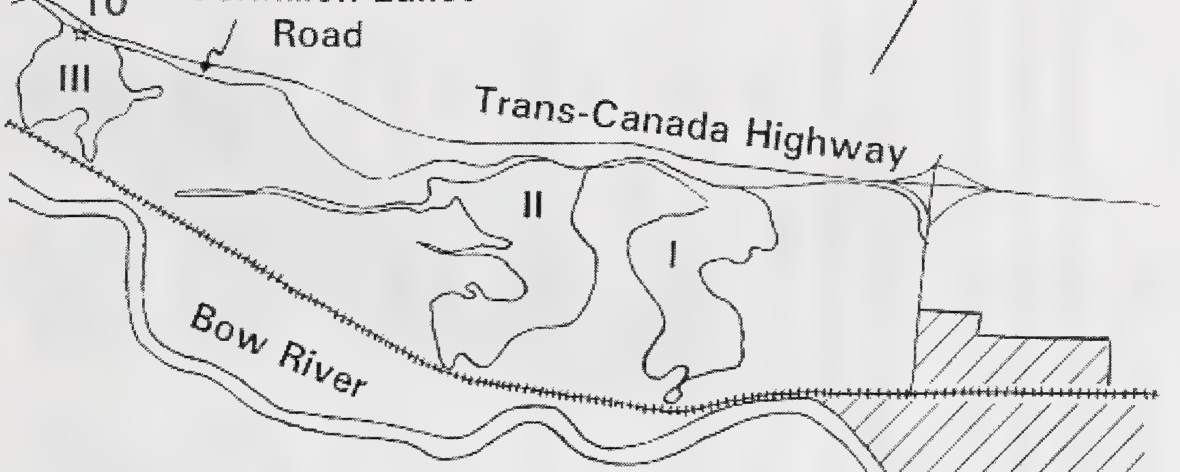

0

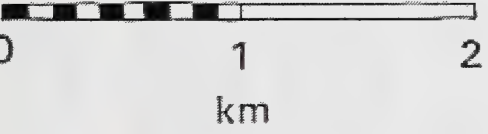

6,7

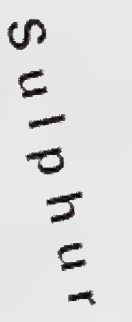

Hotspring

PA Town of Banff 3

Railroad

..... Stream

.... Trail

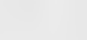

8,9
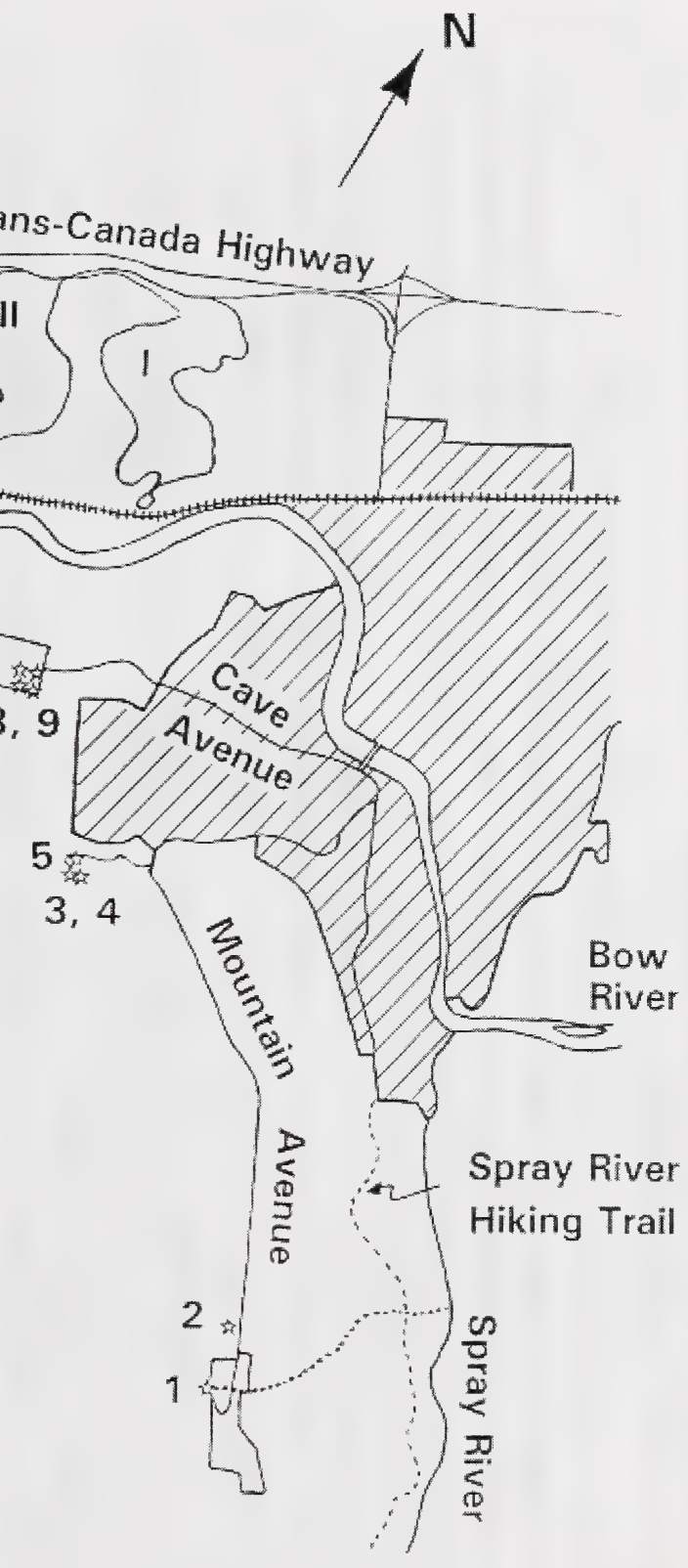

Figure 2. Thermal springs near Banff Townsite, Banff National Park, Alberta (modified from Van Everdingen, 1972). I, II, and III = First, Second, and Third Vermilion Lakes. $1=$ Upper Hot Spring; 2 = Kidney Spring; 3 \& 4 = Upper Middle Springs; 5 = Lower Middle Spring; 6, 7, 8, \& $9=$ Basin, Cave, Lower Cave \& Basin, and Upper C\&B Springs of the Cave and Basin National Historic Site; $10=$ Vermilion Cool Springs at Third Vermilion 


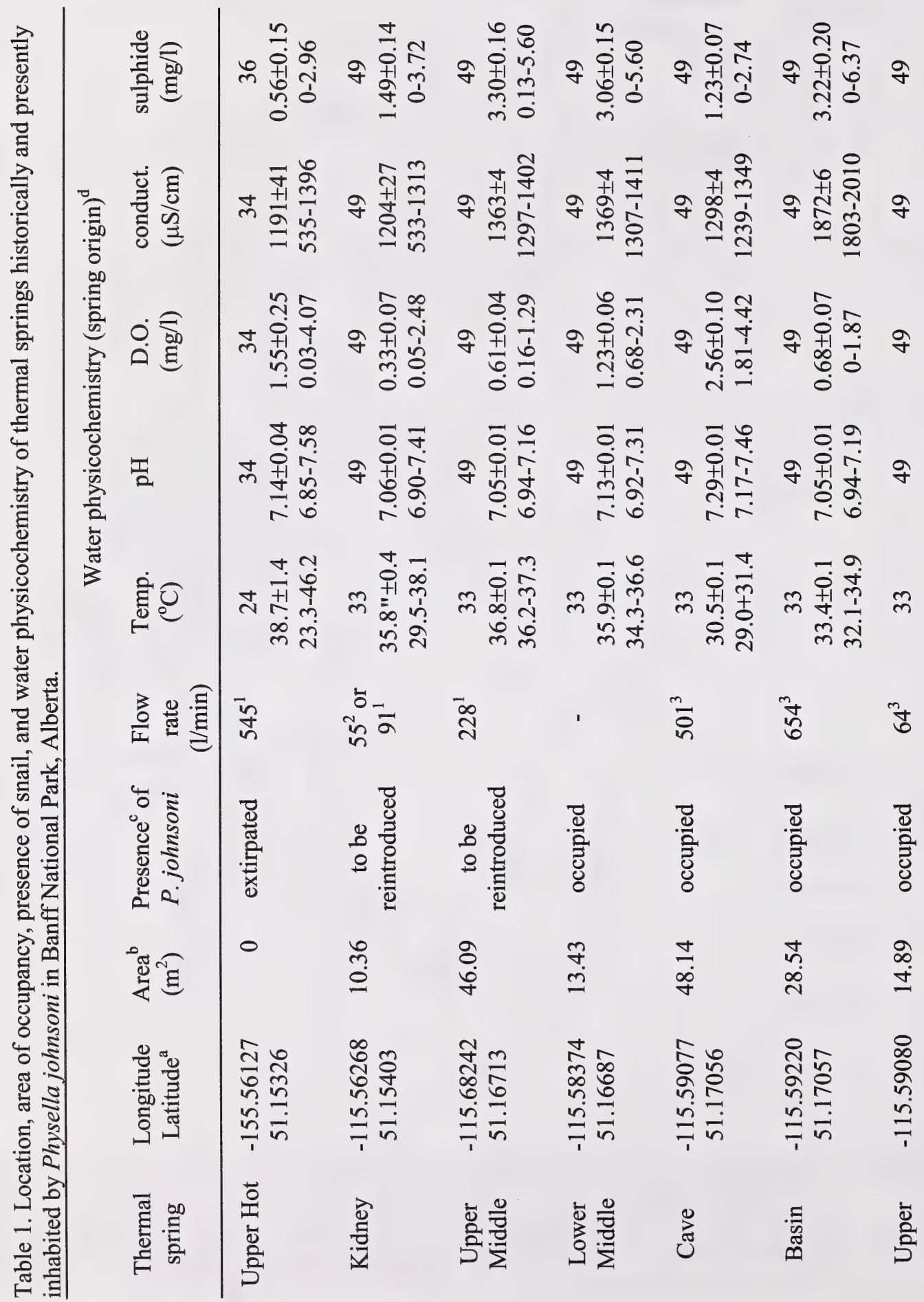




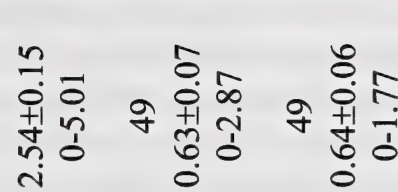

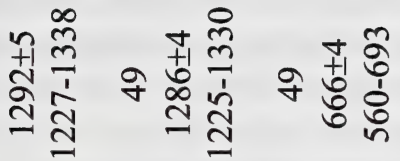

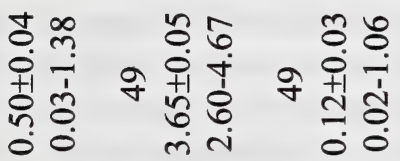

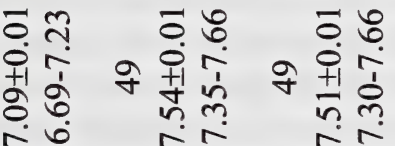

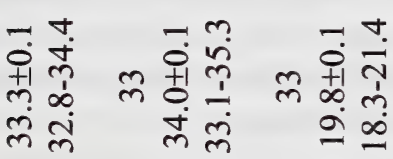

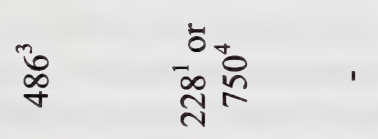

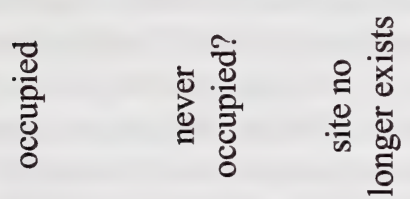

:

के 0 o

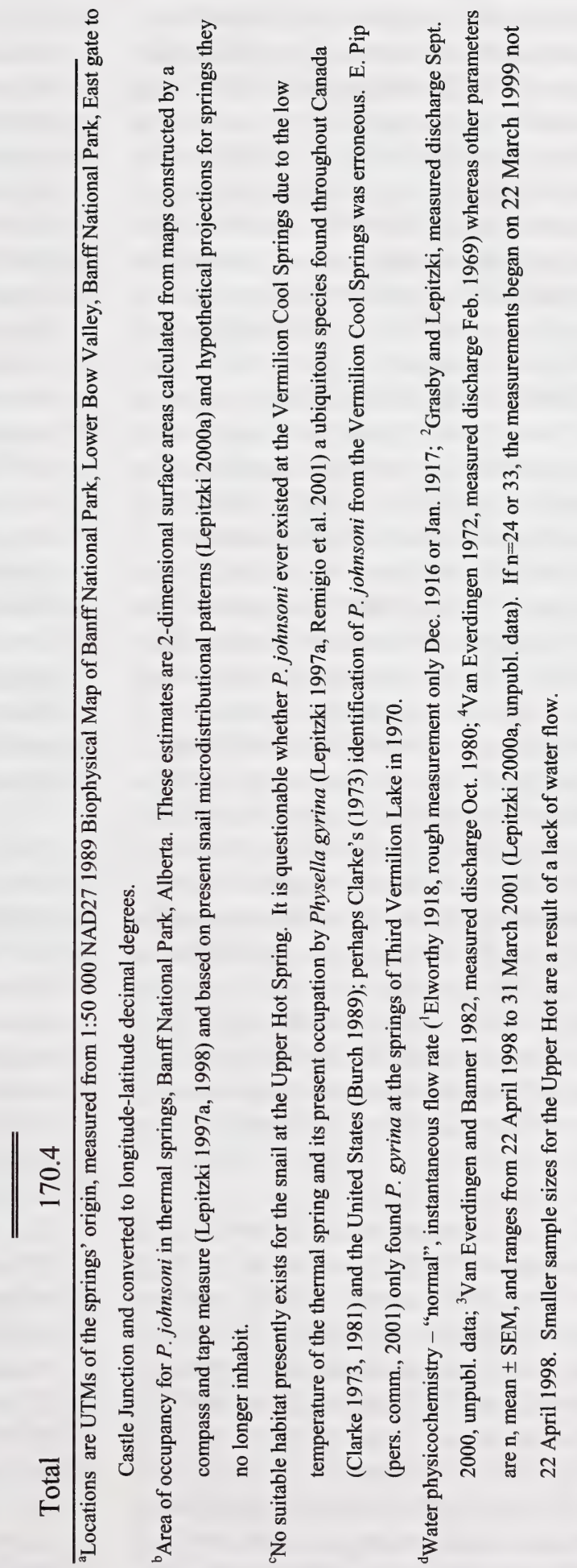

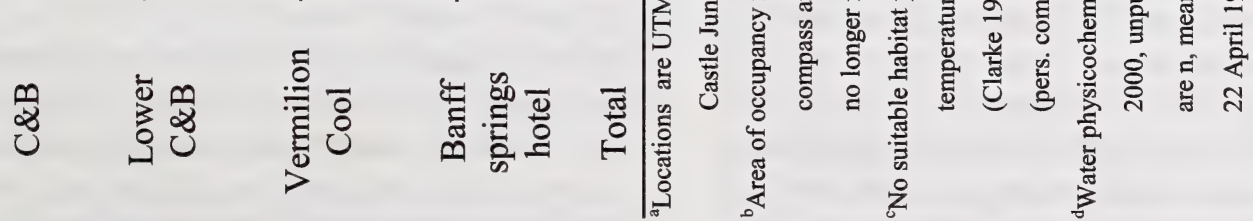


since at least 1918 (Van Everdingen 1972). The Kidney Spring was used as a source for the Banff Springs Hotel swimming pool prior to 1927 (Van Everdingen 1972). Rusting pipes are still found on site. Similarly, remnants of pipes and pieces of concrete are found scattered in the Middle Springs area near the thermal springs' origins although these springs are the least developed and are largely in their natural state (Van Everdingen 1972). Historically, the most famous thermal spring complex in BNP is the Cave and Basin National Historic Site (C\&BNHS). This thermal spring complex consists of four separate springs: Cave, Basin, Upper C\&B, and Lower $\mathrm{C} \& \mathrm{~B}$, the development of which began with the "discovery" of the Cave in 1883. Since then, the Cave and Basin area has been developed and redeveloped (Van Everdingen 1972, Van Everdingen and Banner 1982) to a point that "the natural conditions in the area have been modified irrevocably by the construction of the existing facilities" (Van Everdingen and Banner 1982). Upon surfacing, the water is enclosed in constructed pools and outflow streams; outflow is controlled by a series of drains, pipes, and valves. The Cool Springs at Third Vermilion Lake, a historic location for the Banff springs snail, are the most spatially separate from the others (Figure 2). Although the natural course of the Cool Springs was destroyed during the construction of the Trans Canada Highway in the 1950s (Holroyd and Van Tighem 1983), the warm spring water continues to keep an area of Third Vermilion Lake free of ice during the winter.

Thermal springs can be considered harsh environments with high temperatures, high concentrations of dissolved minerals, and low dissolved oxygen levels (Brues 1924, 1927). Meteoric water (rain and snow) seeping through cracks in the rock of local mountains, is the source for the Sulphur Mountain thermal springs (Figure 2) (Van Everdingen 1972, Grasby et al. 2000). The water is then heated by the thermal gradient of the earth (temperatures rise with increasing depth) and resurfaces along the
Sulphur Mountain Thrust fault (Van Everdingen 1972, Grasby and Hutcheon 2001). The Cool Springs at Third Vermilion Lake (Figure 2) may be similarly driven by water infiltration over Mount Norquay (Van Everdingen 1972). During winter, there is reduced water infiltration, normally causing flow rates to decline during late winter or early spring. However, once snow melt begins in May, the pattern is suddenly reversed as new ground water flows into the system - water temperature, sulphide concentrations, and total dissolved solids concentrations decrease while dissolved oxygen levels and flow rates increase (Van Everdingen 1970). The absence of hydrogen sulphide and the increase in dissolved oxygen are potentially responsible for the complete disruption of the bacterial/algal communities until August (Van Everdingen 1970). This generalized pattern may need to be re-evaluated in light of recent data suggesting the magnitude of the seasonal fluctuations is considerably smaller in all thermal springs, except the Upper Hot and Kidney Springs (Lepitzki 2000a).

The hydrogeological attributes of Banff's thermal springs were studied as early as the 1910s (Satterly and Elworthy 1917, Elworthy 1918, 1926, Warren 1927). More recently, Van Everdingen (1970, 1972), Van Everdingen and Banner (1982), and Grasby et al. (2000) also studied these thermal spring systems. In 1996, water temperatures were measured once every three weeks, until after July 2000, when this changed to once every four weeks (Lepitzki 1997a,b, 1998, 1999, 2000a). Beginning in February 1998, a number of other water chemistry parameters including $\mathrm{pH}$, dissolved oxygen, conductivity, alkalinity, and sulphide, along with hourly water temperatures have also been measured (Table 1).

All the springs historically and presently inhabited by P. johnsoni (Table 1), except for the Vermilion Cool Spring, can be classified as thermal and mineral (total dissolved solids greater than $1000 \mathrm{mg} / \mathrm{L}$ ) (Van Everdingen 1991, 
Lepitzki 1999). Although the Vermilion Cool Spring is thermal, it would be considered freshwater. Using criteria listed in Danks and Williams (1991), the springs could be further classified as most likely permanent $(>1000$ years between major disturbances), limnocrene (discharge to a basin: Upper Middle, Cave, Basin, Upper C\&B, Lower C\&B) or rheocrene (rapid flow on discharge: Upper Hot, Kidney, Lower Middle, and Vermilion Cool Springs), and with a low to medium volume (low $<600 \mathrm{~L} /$ min., medium $600-30000 \mathrm{~L} / \mathrm{min}$ ). On discharge, all springs flow into an outflow stream varying in length (several $10 \mathrm{~s}$ of $\mathrm{m}$ to over 1500 $\mathrm{m})$, width $(10-50 \mathrm{~cm})$, and depth $(0-\sim 30 \mathrm{~cm})$. Substrates normally consist of fine particulate matter, gravel, rocks, and boulders (approximately $20 \mathrm{~cm}$ diameter), which are usually coated with microbial growth. Forest debris (logs, sticks, needles, cones, leaves) and a floating microbial mat are also common in some springs. The submergent vegetation includes a variety of mostly unidentified bacteria and algae (colours include pink, dark red, green, and white).

Some of the thermal springs periodically become dry. The first instance of the Upper Hot Spring drying occurred in 1923 when no water flowed for 8.5 weeks from March to May (Warren 1927). More recently, the Upper Hot Spring becsame dry during late winter in 1998 (21-42 days in April), 1999 (15-19 weeks from February to late May), 2000 (21-23 days in April) and 2001(1619 weeks from February to late May) (Lepitzki unpubl. data). A lower than normal amount of precipitation in 1922 is the proposed cause of the flow stoppage in 1923 (Warren 1927). Similarly, below normal precipitation may be the cause for the recent flow anomalies (S. Grasby, pers. comm.). The first known instance of another Sulphur Mountain thermal spring drying was recorded during the winter of 1995-1996, when no water flowed at the Upper Middle Springs for at least 12 weeks (Lepitzki 1997a).

Microdistributional studies (Lepitzki 1997a,
$1998,1999,2000$ a) suggest that specific and critical habitat attributes for the snail include a steady supply of warm thermal spring water $(\sim 30$ $\left.-38^{\circ} \mathrm{C}\right)$, with high conductivity $(\sim 1200-2000$ $\mu \mathrm{S} / \mathrm{cm}$ ), and noticeably high levels of hydrogen sulphide (up to $\sim 6.0 \mathrm{mg} / \mathrm{L}$ ). The water physicochemistry (physical and chemical measurements) and microclimate result in unique thermal spring ecosystems with siterestricted and extremely localized bacterial/algal communities.

\section{CONSERVATION BIOLOGY}

Snails are members of the Phylum Mollusca. Other molluscs include slugs, mussels, oysters, clams, squids, cuttlefishes, and octopods. Physella johnsoni is a member of the Class Gastropoda, Family Physidae, a group of freshwater snails with a worldwide distribution. All physids have a shell that coils to the left (sinistral - aperture or shell opening is on the left when shell apex or tip is up) whereas all other spiralling, cone-shaped North American freshwater snails have right-coiling shells (dextral). The majority of physids rarely leave the water and are generally restricted to shallow, nearshore margins of aquatic habitats (McMahon 1983).

P. johnsoni is a small, globe-like snail with a short spire (portion of shell above the aperture). The maximum published shell length is $8.8 \mathrm{~mm}$ (Clarke 1973). Snails with shells up to approximately $11 \mathrm{~mm}$ in length are occasionally found although most snails have shells around $5 \mathrm{~mm}$ long (Lepitzki unpubl. data). Shell colours vary from black to light brown and many shells have a white coating which may be microbial growth or mineral precipitates (Lepitzki unpubl. data). A detailed description of the species is found in Clench (1926) and reproduced by Clarke (1973).

Physids have lungs and breathe air (Subclass Pulmonata). In general, most pulmonates return to the water's surface to breathe although some 
species of Physella have been found to rarely undergo this vertical migration (Pennak 1989). Although still highly dependent on pulmonary gas exchange, physids have evolved a rudimentary neomorphic gill with finger-like mantle lobes that reflect back over the shell (McMahon 1983). In P. johnsoni these lobes are reduced (Lepitzki unpubl. data). Most $P$. johnsoni are found at or near the water's surface (Lepitzki 1997a,b), possibly a result of the generally low level of dissolved oxygen and its reduced mantle lobe. Clinging to rocks, sticks, needles, cones, and leaves, at or near the water's surface or to floating microbial mats, the snails are vulnerable to habitat disturbance at the water's surface and to predation by shorebirds or waterfowl.

Pulmonates are usually annual (one generation per year) and semelparous (breed only once, then die) (Brown 1991, Dillon 2000). However, in general, as temperatures increase, snails grow faster, reproduce earlier, and can have multiple generations per year (McMahon 1983). There are no publications on the reproductive biology and longevity of $P$. johnsoni, except for annual reports prepared for Parks Canada (Lepitzki 1997a, 1998, 1999, 2000a). Most likely, $P$. johnsoni are hermaphroditic, similar to other members of the Family Physidae (Clarke 1973, Dillon 2000). In other species of Physella, reproduction is temperature dependent (DeWitt 1955, 1967, Sankurathri and Holmes 1976). Transparent, crescent-shaped, snail egg capsules have been found in three thermal springs (Cave, Basin, Upper C\&B) and egg capsules have been found year-round in the Basin. Very small snails (around $1 \mathrm{~mm}$ shell length) have also been found year-round in the Cave suggesting that reproduction may not be seasonal. Egg capsules have always been found at or slightly above the water's surface, attached to a hard substrate (concrete pool wall, wooden post, floating microbial mat, snail shell) suggesting that atmospheric oxygen is required for development. In flow-through aquaria containing Cave Spring water, egg capsules ranged in size from $1 \times 1 \mathrm{~mm}$ to $3 \times 2 \mathrm{~mm}$, and on average, contained 2.7 eggs per capsule (range 1 to 6 ). These capsules have been found throughout the tanks, not just near the water's surface, and it is thought that capsule position in the tank may reflect the higher dissolved oxygen levels (Lepitzki unpubl. data). Embryos within the eggs grow with a typical sigmoid growth curve, and fully formed snails with shell lengths from $0.5 \mathrm{~mm}$ to $0.8 \mathrm{~mm}$ hatch within 4 to 8 days after deposition. The capsules in aquaria are noticeably smaller than those found in the thermal springs and are produced by snails as small as $3 \mathrm{~mm}$ shell length. Snail fecundity may also be size-dependent (Lepitzki 2000a). The longevity of the species is unknown, but captive adults (approximately $5.0 \mathrm{~mm}$ shell length) have lived for an additional 5 months in recirculating aquaria (Lepitzki 1998).

Freshwater gastropods are either herbivores or detritivores (Brown 1991); physids appear to prefer detritus and/or bacteria (Brown 1991). Aufwuchs (or periphyton: mixed algal, fungal, and bacterial slime communities growing on hard surfaces) (McMahon 1983) is a common food. DeWitt (1955) found that the diet of Physella gyrina consisted of dead and decaying vegetation and living algae and water molds. Clampitt (1970) found a variety of items in the stomachs of $P$. gyrina and Physella integra including the following: diatoms, filamentous algae, green and blue algae, rotifers, crustaceans, pieces of arthropods, small amounts of vascular plant tissue, and sand grains. He concluded the two snail species ate what was available and could be scraped loose in a particular habitat. On several occasions, $P$. johnsoni were observed to ingest white-filamentous bacteria while being photographed through a dissecting microscope (Lepitzki unpubl. data).

Physella johnsoni are likely important grazers in the thermal spring ecosystems. Gastropods can have important effects on algal production including periphyton composition and abundance (Brown 1991). In turn, $P$. johnsoni contributes organic nutrients to the thermal 
springs through excrement. Hebert (1997) suggested that Banff's thermal spring ecosystems could shift with the loss of an important grazer like the Banff springs snail. As such, the Banff springs snail may be a keystone species (a species that makes an unusually strong contribution to community structure or processes and has a disproportionate effect on the rest of the community) in the thermal springs (Meffe and Carroll 1994).

Physella johnsoni is an endemic species and therefore is a valuable biogeographic marker and a unique element of regional biodiversity (Mayhood 1992). Mitochondrial DNA (mtDNA) evidence (Remigio and Hebert 1998, Remigio et al. 2001) suggests that it is a species that recently evolved in situ since the retreat of the glaciers, 10000 to 12000 years ago. These mtDNA results confirm allozyme (Hebert 1997) and morphological evidence (Te 1978, Lepitzki 1998 ) that $P$. johnsoni is a unique and valid taxon - "an endemic species with a brief but significant history of evolutionary divergence" (Remigio and Hebert 1998). The ability of physids to live in thermal springs (Brues 1932) and to tolerate water temperatures up to $44^{\circ} \mathrm{C}$ (McMahon 1983) may have been prerequisites for $P$. johnsoni's ancestors to survive in thermal spring conditions.

One other physid is known to inhabit thermal springs in Canada. The "Endangered" (COSEWIC 2000) hotwater physa Physella wrighti (Te and Clarke 1985) is endemic to Laird River Hotsprings Provincial Park in north-central British Columbia (Te and Clarke 1985, Lee and Ackerman 1999). This species is only found along a $34 \mathrm{~m} \times 2 \mathrm{~m}$ section of an outflow stream. MtDNA evidence suggests that it too has recently evolved (Remigio et al. 2001), a finding that is contrary to an earlier assertion that it may have been a glacial relic (Te and Clark 1985).

\section{DISTRIBUTION}

1. Alberta - Since the species' original description in 1926, P. johnsoni has only been collected in 1965 (Clarke 1973) and 1975 (Parks Canada 1975). The 1927 and 1929 dates of collection in Clarke (1973) are most likely erroneous (A. Baldinger, pers. comm., A. Clarke, pers. comm.). Historic locations were the Upper Hot, Kidney, Middle, Cave and Basin, and Vermilion Cool Springs (Clench 1926, Clarke 1973) (Figure 2). As only one site, an outflow stream near the Banff Springs Hotel that contained the snail was examined in $1965(\mathrm{H}$. Athearn, pers. comm.), it is unknown if the species continued to inhabit all springs after the original collections in the 1920s. Parks Canada subsequently collected the snail from "Middle Springs" in October 1975, but the specific Middle Spring location was not indicated (Parks Canada 1975). The thermal spring outflow stream near the Banff Springs Hotel where the species was collected in 1965 (Clarke 1973), no longer exists (Lepitzki 1997a,b). To Clarke's knowledge the site description is accurate (A. Clarke, pers. comm.) and the person who collected in 1965 has confirmed the location $(H$. Athearn, pers. comm.). Although no shells of $P$. johnsoni have ever been found at the Upper Hot Springs and only a few $(<10)$ have been found at the Kidney Springs, hundreds of shells litter the outflow stream of the Upper Middle Springs. This may imply that the species was only recently extirpated from the Upper Middle Springs. Presently, the species survives in five thermal springs: Lower Middle, Cave, Basin, Upper $\mathrm{C} \& \mathrm{~B}$, and Lower C\&B (Figure 2, Table 1). The Banff springs snail has been extirpated from three thermal springs (Upper Hot, Kidney, Upper Middle) and one cooler spring (Vermilion Cool) (Lepitzki 1997a,b, 1998, 1999, 2000a) (Table 1).

Although this snail is small and inconspicuous, the macrofauna of some western North American springs has been studied since the beginning of the $20^{\text {th }}$ century (Brues 1924, 1927, 1928, 1932). Given the human fascination with thermal springs and the human history and extensive use of BNP, it is extremely unlikely that unknown populations of the snail exist. All known thermal springs along the Sulphur Mountain Thrust Fault 
(Grasby and Hutcheon 2001), including Forty Mile Spring (between Mounts Brewster and Norquay) and six previously undescribed cooler thermal springs in the Middle Springs area (Lepitzki unpubl. data) have been examined for snails (Lepitzki pers. obs.); only five presently contain the snail (Table 1). In March and April 2001, two physid shells were found in another previously undescribed thermal spring in the Middle Springs area (Lepitzki unpubl. data). Lepitzki (unpubl. data) has also examined Miette Hot Springs in Jasper (Grasby et al. 2000) and no snails were found. Others examined the Mist Mountain Spring (Grasby et al. 2000) and only common invertebrates were present (S. Grasby, pers. comm.).

The entire range of the Banff springs snail occurs in Alberta. "Other things being equal, rarity (in relation to range) makes extinction more probable" (Cameron 1998). The current area of occupancy and the hypothetical area that might be occupied once snails are re-established at two thermal springs are given in Table 1. Some annual variation in snail microdistribution does occur, but it is included in these areal estimates. The current hypothetical total area that this species occupies $\left(170 \mathrm{~m}^{2}\right)$ is slightly greater than that of a volleyball court $\left(9 \mathrm{~m} \mathrm{x} 18 \mathrm{~m}=162 \mathrm{~m}^{2}\right)$.

Natural exchange of snails among the five presently inhabited thermal springs is unlikely even though the origin pools of the four springs at the C\&BNHS occur within an area of approximately $3025 \mathrm{~m}^{2}$. The Lower Middle Spring is located approximately $1 \mathrm{~km}$ from the C\&BNHS (Figure 2). Exchange between the Middle Springs and the Cave and Basin area springs may have occurred in the past. At one time, Middle Springs' water was piped to the C\&BNHS (Parks Canada 1958) and water from the Upper C\&B and Lower C\&B Springs was piped into the Basin Spring (Van Everdingen 1972, Van Everdingen and Banner 1982). Blockage of the drain from the Lower C\&B Spring can allow water from this spring to flow into the Cave Spring (Lepitzki pers. obs.); however, the water flows through underground channels and snails most likely would not survive. Similarly, a blocked drain in the Upper C\&B Spring outflow pool can permit water from this spring to flow into the Lower C\&B Spring; however, only four individual $P$. johnsoni have been observed in the Upper C\&B Spring outlet pool since 1996 (Lepitzki unpubl. data). A pipe from the Kidney Spring to the Banff Springs Hotel (Lepitzki pers. obs., Van Everdingen 1972) may have been the conduit for the snails that Athearn found in the outflow stream near the Banff Springs Hotel in 1965 (Clarke 1973).

Not only does $P$. johnsoni have a severely restricted distribution, as it is found only in specific thermal springs, but the snail has a marked microdistribution within each spring (Lepitzki 2000a). Although the causes of the snails' microdistribution are unknown, it may be related to the ecological dynamics of the thermal springs themselves and dependent on the microbial community, or "bottom-up" regulation (regulation from the bottom of the food web through the primary producers as opposed to topdown regulation by predators) (Lepitzki 2000a). Unquantified habitat characteristics that change along outflow streams include the microbial community. The presence and distribution of the microbial food source may dictate the snail's microdistribution; Brown (1991) and Dillon (2000) suggest that other snail populations may be food regulated. Water physicochemical factors significantly correlated (Spearman, $\mathrm{P}<$ 0.05 ) with $P$. johnsoni microdistribution include positive water temperature and hydrogen sulphide conditions and negative $\mathrm{pH}$ and dissolved oxygen (D.O.) levels (Lepitzki 2000a, unpubl. data).

Based on population surveys conducted once every three weeks since January 1996, most snails (upwards of $90 \%$ at certain times of the year) in the Cave, Basin, and Upper C\&B Springs are found within the origin pool, where the warm water surfaces. Snail numbers drop drastically within $10 \mathrm{~m}$ of this area. Similarly, 
most snails in the Lower Middle Spring and the Lower C\&B Springs are found within $10 \mathrm{~m}$ to $20 \mathrm{~m}$ of the origin pool. As such, the origin pool and the first $20 \mathrm{~m}$ of the outflow streams are considered critical habitat (Lepitzki 2000a).

2. Other Areas - Burch (1989) lists the distribution of P. johnsoni as Alberta, Montana, Wyoming, and Colorado. His conclusions are most likely based on shells in museum collections. Given the overwhelming morphological (Te 1978, Lepitzki 1998), allozyme (Hebert 1997), and mtDNA (Remigio and Hebert 1998, Remigio et al. 2001) evidence, it is likely that Burch's (1989) identifications are erroneous. Others do not list $P$. johnsoni as occurring in Wyoming (Wu and Beetle 1995) or Colorado (Wu 1989). As such, the species can be considered endemic only to Alberta.

\section{POPULATION SIZE AND TRENDS}

\section{Alberta - From January 1996 to July 2000,} population surveys occurred once every three weeks at all historic Alberta locations (Lepitzki 1997a, 1998, 1999, 2000a, unpubl. data). After July 2000, they occurred once every four weeks (Lepitzki 2000b). No previous studies have estimated population sizes. The frequency of surveys was changed in July 200 from once every three weeks to once every four weeks (Lepitzki 2000b). Maps of the thermal springs and outflow streams have been drawn with the aid of a compass and tape measure, delineating sections or microsites. The microsite divisions were based on the contour and outline of the thermal spring and outflow stream. Maps are provided in Lepitzki (1997a, 1998). During visual surveys, each of the thermal springs and its outflow stream are intensively searched for snails. Since January 1997, the Upper Hot, Kidney, Upper Middle, and Cool Springs at Third Vermilion Lake have not been intensively searched as no $P$. johnsoni were found in these springs in 1996 (Lepitzki 1997a,b). However, a cursory examination is still made in these springs during water physicochemistry measurements.
In the Cave and Lower C\&B Springs, a head lamp is used to illuminate dark areas. All snails inhabiting each microsite are counted with a hand tally counter. Some microsites are never searched because of their inaccessibility (i.e., cliff faces). Also, snails likely live in pipes that deliver water to the outflow streams, and these can not be counted. It is impossible to accurately determine how much these unassessed microsites would contribute to overall snail numbers. Therefore, snail numbers are considered minimum total population estimates only.

Tesults for each of the five thermal spring snail populations from January 1996 to January 2002 are presented in Figure 3. Analyses for data collected after January 2001 are still pending. Two patterns of snail abundance have been observed. Up until July 2000, the population in the Cave Spring appeared to be the most stable and underwent short periods (approximately 4 months) of population increase and decrease. The relative stability of the Cave Spring environment (i.e. not subjected to external weather influences) may offer an explanation. After July 2000, a plugged drain allowing thermal spring water from the Lower C\&B Spring to enter the Cave Spring provided additional snail habitat (Lepitzki pers. obs.). Consequently, the snail population at the Cave Spring increased significantly $(\mathrm{P}<0.05$, Lepitzki unpubl. data) and then experienced the typical late winter/early spring decline (Figure 3 ). In November 2001, the plugged drain was reopened following an emergency environmental assessment. The additional water flow into the cave ceased and the snail population declined. The other pattern consists of a significantly lower number of snails (Kruskal-Wallis followed by Dunn's, $\mathrm{P}<0.05$ ) (Hollander and Wolfe 1973) during May-August at three springs: Lower Middle Spring, Basin Spring, and Upper C\&B Spring (Lepitzki 2000a, unpubl. data). While the seasonal pattern in the Lower C\&B Spring is less clear and significant $(\mathrm{P}<0.05)$ only in 2000 , this spring has shown the largest 


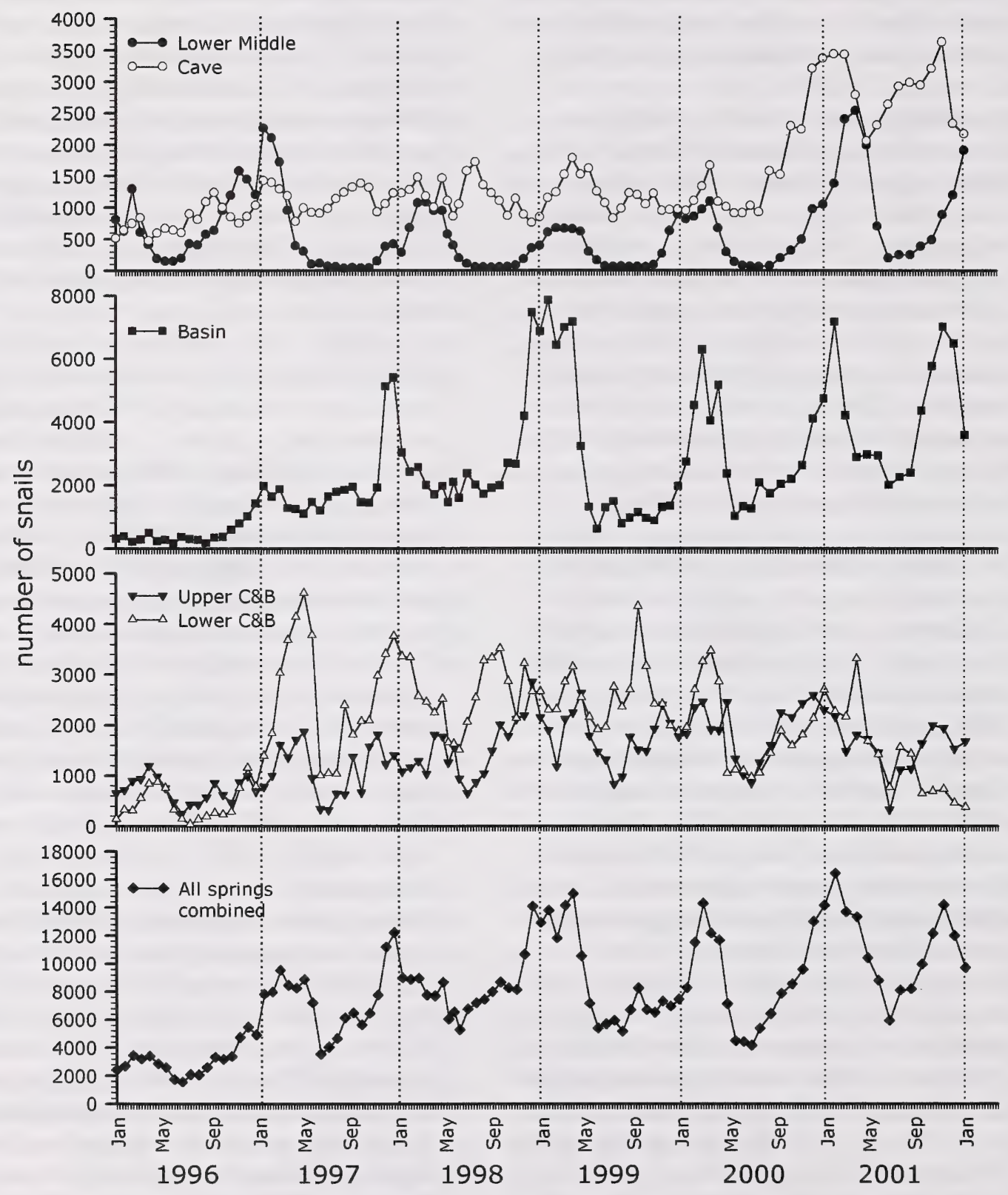

Figure 3. Number of Physella johnsoni in individual thermal springs and all springs combined, Banff National Park, Alberta, January 1996 to January 2002. Counts were done triweekly except between April and June 1998 when they were bi-weekly and after July 2000 when they were quad-weekly. 
magnitude recovery, increasing from a low of 43 snails in July 1996 to over 4500 snails ten months later (May 1997). The Basin Spring has shown the largest decline: from over 7800 snails in mid-January 1999 to slightly over 600 snails at the end of May 1999. When yearly (1996 to 2000) average snail numbers are examined, significant increases were found between 1996 and subsequent years at the Cave, Basin, and Lower C\&B Springs, but these increases levelled off after 1997 (Lepitzki 2000a, unpubl. data). Only the Upper C\&B Spring has experienced a significant yearly (1996 to 2000) increase in snail numbers. While it appears that snail numbers have decreased yearly (1996 to 1999) in the Lower Middle Spring, this decline was not statistically significant (Lepitzki 2000a). The collapse of the Lower Middle Spring origin's roof in early January 2001 may have resulted in a shift in snail microdistribution from areas formerly inaccessible to areas included in the snail count. Consequently, an increase in snail numbers was observed (Figure 3).

The causes of the significant annual (1996 to 2000) increase in snail numbers at the Cave and Basin Springs are unknown, but they may be related to the increased surveillance and protection offered to the snail and its habitat (Lepitzki 1999, 2000a). However, while no additional protective measures have been implemented at the Upper C\&B and Lower C\&B Springs, their annual (1996 to 2000) numbers have also increased significantly. Perhaps the increase in snail numbers at each spring is related to the significant increase in annual water temperatures (Lepitzki 1999, 2000a).

If all five populations are combined, the seasonal pattern of abundance is easily seen, with maxima occurring in late winter/early spring and minima occurring from May to July (Figure 3). If yearly averages are examined from 1996-2000, it is apparent that there was a significant increase ( $P$ $<0.05$ ) in total snail numbers between 1996 and 1997, with subsequent levels in 1998, 1999 and
2000 not significantly different from those of 1997 (Lepitzki 2000a, unpubl. data). Data analysis for 2001 is pending. This increase in total snail number can mostly be attributed to the Basin Spring population. As these are the only population data in existence, it is impossible to indicate a most recent 10 -year trend.

The seasonal fluctuations in density of $P$. johnsoni are exactly opposite to those found for other physids in North America. Clampitt (1974) found that densities of Physella integra were highest in August-September in Michigan. Similarly, Pip and Stewart (1976) found that densities of Physella gyrina peaked from June to July in Manitoba. A general limitation of these studies is that year-round sampling is not possible because of an ice layer during the winter. While Sankurathri and Holmes (1976) also did not sample for Physella gyrina under the ice in their control area, a thermally influenced experimental area of a lake near Edmonton was sampled year-round. Even though $P$. gyrina were found to reproduce year-round in the experimental area, peak snail densities also were recorded during the summer.

The causes of the seasonal population fluctuation in $P$. johnsoni are unknown but may be related to abiotic or biotic factors in the thermal springs. While reproduction appears to be evident yearround, the small and cryptic nature of the snail eggs makes the examination of reproduction in the springs difficult. Artificial snail egg substrates (Boag and Pearlstone 1979, Morris and Boag 1982) may be deployed and monitored in some springs. If reproduction does occur throughout the year, the abundance and quality of food may be important in the population fluctuations as other snail populations can be food-regulated (Brown 1991, Dillon 2000). The seasonal dynamics of the microbial community, the presumed food source for P. johnsoni, could be important and may be indirectly reflected in the associations between snail numbers and water physicochemistry. Significant and positive 
non-parametric Kendall's Tau tests for concordance (Daniel 1990) have been found between annual (1996 to 1999) patterns of snail numbers and dissolved oxygen concentration and conductivity at three of five springs, the two exceptions being springs where physical structures (i.e., small water falls and weirs) inflate dissolved oxygen levels (Lepitzki 2000a). Interestingly, only the springs that had a "Ushaped" seasonal pattern for dissolved oxygen were those that still contained the snail, suggesting that biological activity of unknown origin may be responsible for the concave oxygen pattern.

2. Other Areas - The species is endemic to Alberta and does not occur elsewhere.

\section{LIMITING FACTORS}

\section{Endemicity and Dependence on Rare,} Unique, and Fragile Thermal Spring Habitats - Physella johnsoni is confined to very discrete, highly localized, and extremely small habitat patches. The entire critical habitat for the species, both hypothetical and presently occupied, encompasses only $170 \mathrm{~m}^{2}$ within Banff National Park, Alberta.

On a geological time scale, thermal springs are not permanent. Brues $(1924,1927,1928,1932)$ has done the most extensive and intensive study of thermal springs in western North America. He found evidence of the vast extent and enormous size of earlier springs, now extinct, in areas still containing springs (Brues 1928). Therefore, by the very nature of its habitat, $P$. johnsoni may be prone to extinction.

\section{Habitat Loss and Alteration, and Human} Disturbance - All historic and presently inhabited thermal springs have been affected by humans to a varying degree.

The least altered habitats are in the Middle Springs area. Since the summer of 1995, these springs have been located within areas closed to the public through Banff National Park Superintendent Closures, first for public safety caused by high human fecal pollution (Pacas et al. 1996), then to protect the snail's habitat (Lepitzki et al. 2001a), and thirdly, as of November 1997, because the springs are in the Sulphur Mountain Wildlife Corridor. Unfortunately, even with these restrictions, human use of the Upper Middle Springs cave continues (Lepitzki et al. 2001b). This use includes the construction of rock dams to increase the depth of the origin pool for soaking. When the rock dam is removed, a gush of water scours the outflow stream. An issues analysis has been done to further protect this area (Lepitzki et al. 2001b) and an Environmental Assessment for the preferred option has been written (Lepitzki and Pacas 2001).

Human use of the Kidney Spring also continues. This spring is not within a Superintendent's Closure and receives a higher level of use than the Middle Springs (Lepitzki et al. 2001b). People enjoy soaking in the concrete cistern; and a photograph of this activity is even shown in a hot spring guide book (Woodsworth 1999). Site modifications and/or closures will be required before snails are re-established (Lepitzki et al. 2001b); preferred options are presented in an Environmental Assessment (Lepitzki and Pacas 2001).

While snails will be re-established at the Upper Middle Spring and the Kidney Springs (Lepitzki et al. 2001a,b, Lepitzki and Pacas 2001), the Upper Hot Spring is not considered a viable reintroduction site at this time. The Upper Hot Spring has been experiencing severe water flow reductions and flow cessations (Lepitzki 2000a, unpubl. data). During reduced flows, excess water is not shunted down the outflow stream. When there is sufficient water, water near the spring's origin may be too hot $\left(\sim 47^{\circ} \mathrm{C}\right)$ as the upper temperature limit for physids appears to be $41^{\circ} \mathrm{C}$ (Brues 1924,1927 ) to $44^{\circ} \mathrm{C}$ (McMahon 1983). Used pool water is then returned to the 
outflow stream. Snails should not be reintroduced to the outflow stream below the addition of pool water because the water is chlorinated and may still contain diatomaceous earth, previously used in filters. A change in the Upper Hot Spring water use management protocol and engineered solutions are required before snails are re-established at this historic location (Lepitzki et al. 2001a,b).

The only undisturbed part of the four thermal springs at the C\&BNHS is the origin of the water. All outflow streams have been engineered and constructed with plastic liners, concrete, and pipes. These outflow streams do contain an abundance of bacteria, algae, and vascular plants; however, a species inventory has not been done since the area was redeveloped in 1985. Prior to that, a preliminary inventory was done by Reynolds (1976); however, species identification problems exist (Lepitzki 1999) and the outflow streams were constructed after his study. Presently, wooden boardwalks lead visitors to the thermal spring origin pools and across and along their outflow streams.

While water in the Upper C\&B and Lower C\&B Springs flows naturally down the outflow streams until reaching the drainage pipes, the depth and amount of water in the Cave and Basin Spring pools is controlled by pipes and valves. Difficulties in maintaining a steady water level in the Basin Spring may be a source of adult snail (Lepitzki et al. 2001b) and snail egg death (Lepitzki 2000a). Also, plugged drains in the Lower C\&B Spring have resulted in increased snail habitat and snail numbers in the Cave Spring (Lepitzki unpubl. data) (Figure 3) but they may have detrimental effects on the structural and cultural integrity of the C\&BNHS. Maintenance procedures to clear drains have the potential to kill or displace snails and reduce the amount of available habitat. A balance between maintaining and enhancing critical snail habitat and maintaining the cultural integrity of a National Historic Site is being sought.
Illegal swimming has, until recently, been a recurring problem at the Basin Spring pool (Lepitzki et al. 2001b). This activity can directly kill snails and snail eggs by crushing them, removing them from their substrates, or stranding them above the water. Indirect mortality can result from the destruction or modification of microhabitat components such as the floating microbial mat, rocks, sticks, and logs. Significant alterations in water physicochemistry have been detected following suspected or confirmed swimming incidents as have significant changes in snail microdistribution (Lepitzki 1999). The addition of potentially lethal substances to the water such as alcohol, body lotions, deodorants, sunscreens, insect repellents, perfumes, antimicrobial soaps, lantern fuels, human wastes and bacteria may occur (Lepitzki et al. 2001b). The addition of toxic substances such as soap, shampoo, and oil by bathers was listed as a limiting factor for the "Endangered" (COSEWIC 2000) Physella wrighti of Liard River Hotsprings Provincial Park, north-central British Columbia (Lee and Ackerman 1999). Installation of a motionsensitive audio and video surveillance system and alarm overlooking the Basin Spring pool has resulted in a significant decline in illegal swimming (Lepitzki et al. 2001b); however, the system must operate continuously. Continued vigilance is also required to ensure that these problems are not transferred to other thermal springs.

Additional forms of habitat alteration have been detected and include littering with garbage and coins; throwing and kicking snow balls and pieces of ice; removing and moving natural objects such as the microbial mat, twigs, logs, and rocks (Lepitzki et al. 2001b). These activities have killed adult snails and snail eggs. Littering with coins (the "wishing-well syndrome") may be particularly damaging as copper sulphate was once used as a molluscicide (Swales 1935). Both the Canadian penny and nickle still contain copper; prior to 1997 
Canadian pennies were $98 \%$ copper (Royal Canadian Mint 2001).

Even the removal of garbage from the thermal springs by well-meaning visitors could result in the death of snails if the garbage is not first examined carefully for the small snails.

Less obvious than swimming but certainly more prevalent, limb-dipping, the dipping of feet or hands occurs, with high regularity in the thermal springs at the C\&BNHS (Lepitzki 2000c). The same potentially toxic substances that are on the skin of illegal swimmers could be present on hands and feet. A recent study involving the observation of visitor behaviour determined that on average, $73 \%$ of visitors to the Cave Spring dipped their hands in the water (Lepitzki 2000c). Significantly $(\mathrm{P}<0.05)$ fewer individuals did so at the other thermal springs $(12 \%, 6 \%$, and $8 \%$, Basin Spring, Upper C\&B Springs, and Lower C\&B Springs, respectively), possibly because kneeling is required to reach the water. Considering that nearly 165000 people visited the C\&BNHS during fiscal year 1998/99, this prevalence of limb dippers would translate into over 120450 people per year dipping their limbs into the Cave Spring water. Some interpretive signs that encouraged this activity have been replaced and a large interpretive panel that identifies the problem was installed in 2000 , but the problem still persists. While scientific evidence of the effects of this activity on the thermal spring environment is nonexistent, the precautionary principle (if unsure, decide on the side of caution) and reverse onus (prove that an activity does not lead to an unacceptable consequence before it is allowed to happen) should be considered. Some anecdotal evidence has been gathered that suggests that sunscreens are banned at several snorkelling locations because of the effects on coral reef and fish communities (Holmes 2000, Lepitzki 2000c). An issues analysis has been prepared for this potential problem (Lepitzki et al. 2001b) and solutions are being considered.
3. Water Flow and Climate Change - The effects of thermal spring flow cessations on the snail are unclear. However, $P$. johnsoni has been extirpated from the two thermal springs where water flow stoppages have been recorded: the Upper Hot and Upper Middle Springs (Table 1). Clarke's (1973) claim that the snail was collected from the Upper Hot Spring in 1927 (after the flow stoppage of 1923) may be erroneous, as were the 1927 and 1929 dates Clarke attributed to the collections by $\mathrm{O}$. Bryant (A. Baldinger, pers. comm., A. Clarke, pers. comm.). No snails were found at the Upper Middle Springs early in 1996, before the springs dried (Lepitzki 1997a). Whether an earlier, unrecorded flow stoppage resulted in the species' extirpation from these springs is unknown as the only recorded instance of the Upper Middle Springs drying is during the winter of 1995-1996 (Lepitzki 1997a).

These recent flow anomalies at the Upper Middle and Upper Hot Springs may signal the beginning of severe water flow problems in the thermal springs of Sulphur Mountain. While it is normal for flow rates to decrease as the underground, natural reservoirs are depleted of water during late winter and early spring (Van Everdingen $1970,1972)$, the only previously recorded instance of any Sulphur Mountain thermal spring drying is the Upper Hot Spring in 1923. Climate change projections for Banff National Park suggest that winter and spring precipitation are expected to increase while summer precipitation is expected to decrease (Scott and Suffling 2000). Consequently, the Sulphur Mountain thermal springs are anticipated to remain near current levels or decrease slightly (Scott and Suffling 2000). If the past four years are any indication of the future under these climate change predictions, continued flow anomalies including flow cessations may be expected.

4. Natural Mortality Factors - Predation by waterfowl, common snipe (Gallinago gallinago), robins (Turdus migratorius), and varied thrushes (Ixoreus naevius) may occur. While mallards (Anas platyrhynchos) and blue- 
winged teals (Anas discors) have been seen in the Basin and Lower C\&B Springs, the other birds are very common along the outflow streams, especially early in the spring. Not only will the snails provide food for the birds, but their shells are a major source of calcium for bird eggs (Krapu 1974, Graveland 1996). E. Pip (pers. comm.) has also found snail shells in the gizzard of a swallow. Predation by wandering garter snakes (Thamnophis elegans), active throughout the year at the C\&BNHS (Lepitzki unpubl. data), may also occur. While predation can be considered a natural mortality factor, control might be considered if snail populations are extremely small, as has been documented in certain springs at certain times of the year.

Another natural mortality factor which could be controlled is the formation of "twitch-ups" along thermal spring outflow streams. These have been noticed following heavy, wet snowfalls when adjacent shrubs and tree-tops are bowed into the streams. The limbs quickly become colonized by bacteria/algae which then provide a substrate for the snails. Once the snow melts, the tree-top is twitched-up, causing the snails to be stranded. Over 100 of these "quick-frozen" snails have been found in several incidents (Lepitzki 1998). Pruning back the adjacent trees and shrubs may be a solution; however, the importance of these trees in providing broken-twig substrates and a pulse of organic material from leaf-fall should be considered.

The potential effects of disease and parasites on mortality of $P$. johnsoni are unknown as no snails have been necropsied or examined for parasites. Physids are known intermediate hosts for a variety of digenea (gastro-intestinal, parasitic flat-worms) whose definitive hosts (habitat of the adult parasite) are vertebrates such as waterfowl (Olsen 1974).

\section{Public Attitudes Toward Invertebrates and} Invertebrates in Protected Areas - Any basic biology textbook usually has a pie-chart showing the realm of known animal life divided into the major phyla; following behind the most speciose group, the arthropods, are the molluscs. Since 1600 , between $37 \%$ and $40 \%$ of the known animal species that have become extinct are molluscs (Wells 1995, Seddon 1998). Furthermore, $80 \%$ of the known mollusc extinctions are island species (Wells 1995). It could easily be argued that $P$. johnsoni is an island species, confined to islands of thermal springs. While most extinct molluscs are terrestrial (Wells 1995), aquatic fauna are proportionally more threatened with extinction than are terrestrial and a large proportion of the world's freshwater fauna appears vulnerable to extinction (Richter et al. 1997). Yet, charismatic megafauna continue to receive the vast majority of time, effort, and money in the conservation community (Erhlich 1992, Ponder 1995). Erhlich (1992) suggested that the preservation of more obscure organisms is crucial. This imbalance began to be addressed in 1994 when the mandate of COSEWIC was expanded to include invertebrates, with the Lepidoptera and Mollusca Sub-committee being formed in 1995 (Metcalfe-Smith et al. 1998). Endangered invertebrates began to be recognized in Alberta's Wildlife Act and Wildlife Regulation (Province of Alberta 2000) in 1996 (D. Vujnovic, pers. comm.). More recently, Alberta's molluscs have had preliminary status ranks assigned (Clifford 2001, Lepitzki 2001).

Once invertebrates are recognized as being essential components of ecosystems, their preservation and conservation requires a very different approach from that of vertebrates (Erhlich 1992, Ponder 1995). Erhlich (1992) and Ponder (1995) suggested that the best tactic for invertebrate conservation is to ensure that their habitats are located within conservation reserves or large protected areas such as National Parks. Wells (1995) agrees that the establishment of protected areas is one essential element for molluscan conservation; however, the presence of threatened molluscs within existing protected areas is not a guarantee that will automatically lead to their conservation. Because of the precise 
habitat requirements and localized distributions of molluscs, specific conservation actions are also required (Kirby 1992 in Wells and Chatfield 1995). Another endemic species confined to the Cave and Basin Marsh in BNP has already been classified as "Extinct." While there is still debate on the taxonomic uniqueness of the Banff longnose dace (Rhinichthys cataractae smithi) (J. Nelson, pers. comm. believes it is an ecophenotype and not a valid subspecies), the status report of Lanteigne (1987) prompted COSEWIC to list it as "Extinct" as of 1986 (COSEWIC 2000).

\section{STATUS DESIGNATIONS}

1. Alberta - Physella johnsoni is currently ranked "May Be At Risk" in Alberta (see Appendix 1 for status definitions) (Lepitzki 2001). While this was the first formal designation in the province, Clarke (1977) suggested that the species was "clearly endangered and should be protected" and Achuff et al. (1986) identified the snail as a "Special Resource of Banff National Park" and suggested it was "vulnerable because of its restricted distribution and it is threatened by development of the springs in which it occurs". Similarly, the Banff-Bow Valley Study identified the species as being "acutely endangered" (Pacas et al. 1996). The Alberta Natural History Information Centre began inputting data on P. johnsoni into their database in 1999 (W. Nordstrom, pers. comm.) although gastropods are not on the tracking lists (D. Vujnovic, pers. comm.). The species has not yet been identified as an "Endangered" invertebrate in Schedule 6 of the Alberta Wildlife Regulation (Province of Alberta 2000).

2. Other Areas - Physella johnsoni has been listed as "Threatened" by COSEWIC since 1997 (COSEWIC 2000) based on the status report of Lepitzki (1997b). Reasons for this designation included drastic population fluctuations, disappearance from some of its former range, and presence in areas of high human use areas. It was not listed as "Endangered" because of its apparent resilience in a high human use area and its existence in five different populations. It was believed that any cataclysmic event would likely affect only one spring at a time, meaning extirpated populations could be re-established from the remaining springs if necessary (B. Aniskowicz-Fowler, pers. comm.). In 2000, the species was reassessed and uplisted to "Endangered" after COSEWIC adopted new criteria based on those used by the IUCN (The World Conservation Union) (COSEWIC 2000). This category was assigned because of the snail's extremely limited distribution, the fluctuations in numbers were greater than one order of magnitude, and threats to the species and its habitat still existed (B. Aniskowicz-Fowler, pers. comm.).

\section{RECENT MANAGEMENT AND RESEARCH IN ALBERTA}

Prior to the Banff Spring Snail Research and Recovery Program in 1996, all that was known about the snail was its historic distribution in the 1920s and from its last collection in 1965 (Clench 1926, Clarke 1973, 1977, 1981). During the fall of 1995 , a simple environmental assessment was prepared for Heritage Conservation, Banff National Park (the Warden Service) to determine the consequences of removing the rock and gravel dam in the Upper Middle Springs cave (Lepitzki 1995). Because the snail no longer inhabited the Upper Middle Springs, removing the dam did not impact the snail. Concurrently, the Upper Hot Spring, an historic location for the snail (Table 1), was undergoing renovations in 1995/96 and a study began to determine the status and distribution of the species in the Park (Lepitzki 1997a). Once again, because the snail had been extirpated from the Upper Hot Spring, no mitigations were required for the snail. Data from the status and distribution study in 1996 were then compiled into a COSEWIC Status Report (Lepitzki 1997b). The above studies and reports led to the beginning of the Research and Recovery Program, which has resulted in annual reports 
being written for the jurisdictional authority, Parks Canada (Lepitzki 1997a, 1998, 1999, 2000a). These reports are available through the Banff National Park Warden Service Library.

The annual reports contain information on population surveys conducted once every three weeks, snail microdistributional patterns, and information on water temperatures in all historic locations. In addition, they list management recommendations and directions for future research. Beginning in February 1998, water physicochemistry was also measured during these surveys. A second draft of the Resource Management Plan (RMP) for the Recovery of the Snail was written in July 1998 and combining guidelines from the Recovery of Nationally Endangered Wildlife (RENEW 1994) and guidelines and management directives of Parks Canada (1986, 1992). This draft RMP has undergone revision and updating (Lepitzki et al. 2001a). Completion and signing off by Parks Canada officials is anticipated by 31 March 2002. Thereafter, the RMP will be formally submitted to RENEW as a Recovery Plan. Many of the actions detailed in the RMP have also been identified in the global strategy to conserve molluscs (Seddon et al. 1998).

The overall goal of the draft RMP is to within 5 years (i.e., by 2006), re-establish self-sustaining populations of the Banff springs snail at all of its historic thermal spring locations (the Upper Middle, Kidney, and Upper Hot) while maintaining and enhancing present populations. This may enable down-listing by COSEWIC; however, due to the precarious existence of the snail and its endemicity, de-listing may never be possible. Nevertheless, additional populations would improve the species' status and increase the probability of its long-term survival. (Lepitzki et al. 2001a).

This will be achieved by the coordinated effort of the three prongs of the plan: science, communications, and protection.
1. Science - Data will continue to be collected on the biology and ecology of the species in the thermal springs through periodic surveys. The frequency of surveys was recently changed from once every three weeks to once every four weeks after a power analysis was completed (Lepitzki $2000 \mathrm{~b}$ ). The influence of water physicochemistry on population changes and microdistributional patterns will continue to be examined. Additional information on the geothermal and chemical dynamics of the thermal springs will be gathered in cooperation with Dr. S. Grasby (Geological Survey of Canada, Calgary). Data on the reproductive biology of the species will continue to be collected in flow-through aquaria, the anticipated source of snails for re-introductions. An environmental assessment under the guidelines of the Canadian Environmental Assessment Act (CEAA) has been written for snail reestablishments (Lepitzki and Pacas 2001) and public comments were incorporated. An important aspect of the RMP is the initiation of a comprehensive resource reconnaissance of the thermal springs. The prioritized components are the following: microbial community, micro and macro invertebrates, vascular plants, and vertebrates. Data gathered will be incorporated into management actions made by Parks Canada managers in order to achieve the goal of the RMP.

\section{Communications - A communications} strategy has been formalized by Parks Canada communication specialists (Dalman 2000). The objective is to increase understanding, awareness, and appreciation of the Banff springs snail amongst Parks Canada staff, local residents, Albertans, Canadians, and international visitors. This will be achieved through the local and national media, interpretive displays, and public presentations. Sectors of the public suspected of causing the most snail habitat disturbance will be specifically targeted in order to curb their activities. Scientific presentations will continue to be given at regional, national, and international 
conferences. Results are expected to be written, submitted, and published in peer-reviewed scientific journals.

3. Protection - Even though Canada does not have endangered species legislation, many of the provisions to ensure the continued survival of the species and the protection of its habitat are contained in the National Parks Act. Additional protection may be offered to this snail through provisions protecting endangered invertebrates found in Alberta's Wildlife Act (Province of Alberta 2000). A federal Endangered Species $A c t$ is also pending (Minister of the Environment 2001). A comprehensive evaluation of habitat disturbances at presently inhabited and reintroduction sites has been written, revised, and is now undergoing further internal review (Lepitzki et al. 2001b). This document also contains an issues analysis of problems and solutions for each thermal spring.

\section{SYNTHESIS}

The Banff springs snail (Physella johnsoni), is a small, inconspicious freshwater snail that is endemic and confined to five thermal springs on Sulphur Mountain, in Banff National Park, Alberta. Since the species was first described in 1926, it has been extirpated from four other thermal and cool springs, all near the town of Banff. The snail is a habitat specialist, dependent on a steady supply of thermal spring water high in dissolved minerals and hydrogen sulphide. Existing populations undergo large magnitude population fluctuations; most snails are found close to where the spring water bubbles to the earth's surface. Unidentified abiotic or biotic factors present in the thermal springs may be responsible for the population fluctuations and microdistributional patterns. Because of the limited number of populations, large magnitude population fluctuations, and four of the five populations being in an area of high human use, COSEWIC designated the snail as "Threatened" in 1997 and then uplisted it to "Endangered" in 2000 (COSEWIC 2000). In Alberta, the species is ranked “At Risk" (Lepitzki 2001).

Actions necessary to ensure the species' continued existence are outlined in a draft Resource Management Plan (Lepitzki et al. 2001a,b), currently undergoing internal review. The three prongs of the RMP, science, communications, and protection, will act in concert. The timely implementation of this recovery plan is the sole management requirement to ensure that the species continues to survive. This will require continuing the provisions of time, money, and dedication as well as a willingness to expend the effort to conserve a microfaunal species that the general public has difficulties acknowledging. Doing so will increase public awareness and understanding of biological diversity and the interconnectedness of all life forms. 


\section{LITERATURE CITED}

Achuff, P.L., I. Pengelly, and C. White. 1986. Special resources of Banff National Park. Environment Canada: Parks. Banff National Park Warden Service. 141 pp.

Alberta Fish and Wildlife. 1985. A policy for the management of threatened wildlife in Alberta. Alberta Fish and Wildlife, Edmonton, AB. 34 pp.

Alberta Sustainable Resource Development. 2001. The General Status of Alberta Wild Species 2000. Alberta Sustainable Resource Development, Fish and Wildlife Service, Edmonton, AB. 46 pp.

Boag, D.A., and P.S.M. Pearlstone. 1979. On the life cycle of Lymnaea stagnalis (Pulmonata: Gastropoda) in southwestern Alberta. Can. J. Zool. 57:353-362.

Brown, K.M. 1991. Mollusca: Gastropoda. Pp. 285-314 in Ecology and Classification of North American Freshwater Invertebrates (Thorp, J.H., and A.P. Covich, eds). Academic Press, San Diego, CA.

Brues, C.T. 1924. Observations on animal life in the thermal waters of Yellowstone Park, with a consideration of the thermal environment. Proc. Am. Acad. Arts Sci. 59:371-437.

Brues, C.T. 1927. Animal life in hot springs. Quart. Rev. Biol. 2:181-203.

Brues, C.T. 1928. Studies on the fauna of hot springs in the western United States and the biology of thermophilous animals. Proc. Am. Acad. Arts Sci. 63:139-228.

Brues, C.T. 1932. Further studies on the fauna of North American hot springs. Proc.
Am. Acad. Arts Sci. 67:185-303.

Burch, J.B. 1989. North American freshwater snails. Malacological Publications, Hamburg, MI. 365 pp.

Cameron, R.A.D. 1998. Dilemmas of rarity: biogeographical insights and conservation priorities for land Mollusca. In Molluscan conservation: a strategy for the $21^{\text {st }}$ century. J. Conch. Spec. Publ. 2:51-60.

Clampitt, P.T. 1970. Comparative ecology of the snails Physa gyrina and Physa integra (Basommatophora: Physidae). Malacologia 10:113-151.

Clampitt, P.T. 1974. Seasonal migratory cycle and related movements of the fresh-water pulmonate snail, Physa integra. Am. Midl. Nat. 92:275-300.

Clarke, A.H. 1973. The freshwater molluscs of the Canadian Interior Basin. Malacologia 13:1-509.

Clarke, A.H. 1977. The endangered molluscs of Canada. Pp. 148-150 in Canada's Threatened Species and Habitats: Proceedings of the symposium (T. Mosquin and C. Suchal, eds.). Special Publication No. 6., Canadian Nature Federation, Ottawa, ON. 185 pp.

Clarke, A.H. 1981. The freshwater molluscs of Canada. National Museum of Natural Sciences, National Museums of Canada, Ottawa, ON. 446 pp.

Clench, W.J. 1926. Three new species of Physa. Occ. Papers Mus. Zool., University of Michigan, 168:1-8.

Clifford, H.F. 2001. Bivalves: 2000 Preliminary Status Ranks for Alberta. Prepared for Alberta Sustainable Resource 
Development, Fish and Wildlife Division, Edmonton, AB. 41 pp.

COSEWIC. 2000. Canadian species at risk, November 2000. Committee on the Status of Endangered Wildlife in Canada. Canadian Wildlife Service, Environment Canada, Ottawa, ON. 24 pp.

COSEWIC. 2002. Database. Committee on the Status of Endangered Wildlife in Canda. URL: http://www.cosewic.gc.ca [Last Updated: 21 January 2002].

Dalman, M. 2000. Appendix II: The threatened Banff springs snail communications strategy. Unpubl. draft rept. prepared for Parks Canada for inclusion in Resource Management Plan for the Recovery of the Banff Springs Snail (Physella johnsoni) in Banff National Park, Alberta. 11 May. 5 pp.

Daniel, W.W. 1990. Applied non-parametric statistics. $2^{\text {nd }}$ edition. PWS-Kent Publishing Co., Boston, Massachusetts. $635 \mathrm{pp}$.

Danks, H.V., and D.D. Williams. 1991. Arthropods of springs, with particular reference to Canada: synthesis and needs for research. Mem. ent. Soc. Can. 155:203-217.

DeWitt, R.M. 1955. The ecology and life history of the pond snail, Physa gyrina. Ecology $36: 40-44$.

DeWitt, R.M. 1967. Stimulation of egg production in a Physid and a Lymnaeid. Malacologia 5:445-453.

Dillon, R.T. Jr. 2000. The ecology of freshwater molluscs. Cambridge University Press, Cambridge, UK. 509 pp.

Elworthy, R.T. 1918. Mineral springs of
Canada. Part II. The chemical character of some Canadian mineral springs. Department of Mines, Mines Branch, Canada, Report 472, Bulletin 20. 173 pp.

Elworthy, R.T. 1926. Hot springs in western Canada - their radioactive and chemical properties. Department of Mines, Mines Branch, Canada, Report 669:1-33.

Grasby, S.E., and I. Hutcheon. 2001. Controls on the distribution of thermal springs in the southern Canadian Cordillera. Can. J. Earth. Sci. 38:427-440.

Grasby, S.E., I. Hutcheon, and H.R. Krouse. 2000. The influence of water-rock interaction on the chemistry of thermal springs in western Canada. Applied Geochemistry 15:439-454.

Graveland, J. 1996. Avian eggshell formation in calcium-rich and calcium-poor habitats: importance of snail shells and anthropogenic calcium sources. Can. J. Zool. 74:1035-1044.

Hebert, P.D.N. 1997. Allozyme divergence in the physid snails of Banff - evidence for a thermal spring endemic. Unpubl. final rept. prepared for D. Lepitzki, Wildlife Systems Research, Banff, AB. November. 9 pp. [In Lepitzki, 1998, 4 July]

Hollander, M., and D.A. Wolfe. 1973. Nonparametric statistical methods. John Wiley and Sons, New York, NY. 503 pp.

Holmes, B. 2000. Snorkelling? Get the right stuff. Westworld Alberta. September. 26(4):48.

Holroyd, G.L., and K.J. Van Tighem. 1983. The ecological (biophysical) land classification of Banff and Jasper 
National Parks. Volume III. The wildlife inventory. Canadian Wildlife Service, Edmonton for Parks Canada, Western Region. $691 \mathrm{pp}$.

Kirby, P. 1992. Habitat management for invertebrates: a practical handbook. Sandy, UK. $150 \mathrm{pp}$. in Wells and Chatfield, 1995.

Krapu, G.L. 1974. Feeding ecology of pintail hens during reproduction. Auk 91:278290.

Lanteigne, J. 1987. Status report on the Banff longnose dace Rhinichthys cataractae smithi in Canada. Committee on the Status of Endangered Wildlife in Canada. $19 \mathrm{pp}$.

Lee, J., and J.D. Ackerman. 1999. Status of the Hotwater Physa, Physella wrighti Te and Clarke 1985. Rept. prepared for the Committee on the Status of Wildlife in Canada (COSEWIC) Secretariate. January. $22 \mathrm{pp}$.

Lepitzki, D.A.W. 1995. Potential impacts on the endangered Banff springs snail (Physa johnsoni) of removal of the earthen dam from the mouth of the left cave at Middle Springs, Banff National Park, Alberta. Unpubl. rept. prepared for the Environmental Assessment Office, Banff National Park, Banff, AB. 19 October. 6 pp.

Lepitzki, D.A.W. 1997a. The status and distribution of the Banff springs snail Physella johnsoni (Clench, 1926) in Banff National Park. Unpubl. final rept. submitted to the Hot Springs Enterprise Unit of Parks Canada, Banff National Park, Banff, AB. 27 March. 112 pp.

Lepitzki, D.A.W. 1997b. Status report on the Banff Springs Snail Physella johnsoni
(Clench, 1926) in Canada. Unpubl. final rept. prepared for the COSEWIC Secretariate. 12 January. $36 \mathrm{pp}$.

Lepitzki, D.A.W. 1998. The ecology of Physella johnsoni, the threatened Banff springs snail. Unpubl. final rept. (1997/98) prepared for Heritage Resource Conservation - Aquatics, Banff National Park, Banff, AB. 4 July. 146 pp.

Lepitzki, D.A.W. 1999. The ecology of Physella johnsoni, the threatened Banff springs snail. Unpubl. annual rept. (1998/99) prepared for Heritage Resource Conservation - Aquatics, Banff National Park, Banff, AB. 31 August. 301 pp.

Lepitzki, D.A.W. 2000a. The ecology of Physella johnsoni, the endangered Banff springs snail. Unpubl. annual rept. (1999/2000) prepared for Heritage Resource Conservation (Aquatics), Banff National Park, Banff, AB. 29 September. $150 \mathrm{pp}$.

Lepitzki, D.A.W. 2000b. Effects of varying the sampling regime in the Banff springs snail (Physella johnsoni) research and recovery program. Unpubl. rept. prepared for Heritage Resource Conservation (Aquatics), Banff National Park, Banff, AB. 29 July. 12 pp.

Lepitzki, D.A.W. 2000c. Quantification of limb dippers at the Cave and Basin National Historic Site. Unpubl. draft rept. prepared for Heritage Resource Conservation (Aquatics), Banff National Park, Banff, AB. 11 September. 5 pp.

Lepitzki, D.A.W. 2001. Gastropods: 2000 Preliminary Status Ranks for Alberta. Prepared for Alberta Sustainable Resource Development, Fish and Wildlife Division, Edmonton, AB. 126 pp. 
Lepitzki, D.A.W., and C. Pacas. 2001. Reestablishment of the endangered Banff springs snail (Physella johnsoni) following habitat protection. An Environmental Screening prepared for Parks Canada, Banff National Park, Banff, AB. 5 June. 33 pp.

Lepitzki, D.A.W., C. Pacas, and M. Dalman. 2001a. Resource management plan for the recovery of the Banff springs snail (Physella johnsoni) in Banff National Park, Alberta. Unpubl. ninth draft prepared for Banff National Park, Banff, AB. 15 October. 45 pp. + appendices.

Lepitzki, D.A.W., B. Low, and C. Pacas. 2001 b. Appendix I: Protection strategy for the Banff springs snail, Physella johnsoni, in Banff National Park. Unpubl. sixth draft prepared for Parks Canada for inclusion in Resource Management Plan for the Recovery of the Banff springs snail (Physella johnsoni) in Banff National Park, Alberta. 15 October. 26 pp.

Litton, E. 1998. Hiking hot springs in the Pacific northwest. Falcon Publishing Inc., Helena, MT. 333 pp.

Mayhood, D.W. 1992. A preliminary assessment of the native fish stocks of Jasper National Park. Part 3 of a Fish Management Plan for Jasper National Park. FWR Freshwater Research Limited, Calgary, Alberta. Unpubl. rept. prepared for Canadian Parks Service, Jasper National Park, Jasper, AB. 296 pp.

McMahon, R.F. 1983. Physiological ecology of freshwater pulmonates. Pp. 359-430 in Mollusca (W.D. Russell-Hunter, eds.), Volume 6, Ecology. Academic Press. San Diego, CA.
Meffe, G.K., and C.R. Carroll. 1994. Principles of Conservation Biology. Sinauer Assoc., Sunderland, MS. 600 pp.

Metcalfe-Smith, J.L., S.K. Staton, G.L. Mackie, and N.M Lane. 1998. Selection of candidate species of freshwater mussels (Bivalvia: Unionidae) to be considered for national status designation by COSEWIC. Can. Field-Nat. 112:425440.

Minister of the Environment. 2001. Bill C-5, an Act respecting the protection of wildlife species at risk in Canada. First reading, 2 February 2001. Public Works and Government Services Canada Publishing, Ottawa, ON. 77 pp.

Morris, J.R., and D.A. Boag. 1982. On the dispersion, population structure, and life history of a basommatophoran snail, Helisoma trivolvis, in central Alberta. Can. J. Zool. 60:2931-2940.

National Research Council. 1995. Science and the Endangered Species Act. National Academy Press, Washington, DC. 271 pp.

NatureServe: An online encyclopedia of life [web application]. 2001. Version 1.4 . Arlington, Virginia, USA: Association for Biodiversity Information. Available: http://www.natureserve.org/ [Accessed: 13 February 2002].

Olsen, O.W. 1974. Animal parasites their life cycles and ecology. Dover Publications, New York. 562 pp.

Pacas, C., D. Bernard, N. Marshall, and J. Green. 1996. State of the Banff-Bow Valley: A Compendium of Information. Prepared for the Banff-Bow Valley Study. Department of Canadian Heritage, 
Ottawa, ON. October 1996. 291 pp. and appendices.

Parks Canada. 1958. Difficulties in using hot sulphide waters in swimming pools in Banff and Jasper National Parks. Internal memorandum for the Chief Engineer from the Supervising Engineer. 25 July. $4 \mathrm{pp}$.

Parks Canada. 1975. Internal memo to Assistant Park Naturalist from University of Calgary. 7 October. $1 \mathrm{pp}$.

Parks Canada. 1986. Management Directive 2.4.3. The designation and management of rare, threatened and endangered species. Natural Resources Division. 8 pp. + appendices

Parks Canada. 1992. Natural Resources Management Process Manual (NRMPM). Environment Canada, Parks Service. $164+$ pp.

Pennak, R.W. 1989. Fresh-water Invertebrates of the United States, Protozoa to Mollusca. $3^{\text {rd }}$ edition, John Wiley and Sons, New York. 628 pp.

Pip, E., and J.M. Stewart. 1976. The dynamics of two aquatic plant-snail associations. Can. J. Zool. 54:1192-1205.

Ponder, W.F. 1995. The conservation of nonmarine molluscs in perspective. Pp. 5567 in Biodiversity and conservation of the Mollusca, (A.C. van Bruggen, S.M. Wells, and Th.C.M. Kemperman, eds.). Proceedings of the Alan Solem Memorial Symposium on the biodiversity and conservation of the Mollusca at the $11^{\text {th }}$ International Malacological Congress, Siena, Italy, 1992. Backhuys Publishers, the Netherlands.
Pritchard, G. 1991. Insects in thermal springs. Mem. ent. Soc. Can. 155:89-106.

Province of Alberta. 2000. Wildlife Act (Statutes of Alberta, 1984, Chapter W9.1 with amendments in force as of February 15,2000) and Wildlife Regulation (Alberta Regulation 143/97 with amendments up to and including Alberta Regulation 215/2000 and Alberta Regulation 2/2001). Queen's Printer for Alberta. 53 and $271 \mathrm{pp}$.

Remigio, E.A., and P.D.N. Hebert. 1998. A thermal spring endemic physid snail: mitochondrial DNA sequence evidence of a recent origin. Unpubl. rept. for Parks Canada and Wildlife Systems Research. September. 24 pp. [in Lepitzki, 1999, 31 August]

Remigio, E.A., D.A.W. Lepitzki, J.S. Lee, and P.D.N. Hebert. 2001. Molecular systematic relationships and evidence for a recent origin of the thermal spring endemic snails Physella johnsoni and Physella wrighti (Pulmonata: Physidae). Can. J. Zool. 79:1941-1950.

RENEW. 1994. Format guidelines for preparing recovery plans for extirpated, endangered and threatened terrestrial vertebrates. Prepared for Recovery of Nationally Endangered Wildlife by the Canadian Wildlife Service, Ottawa, ON. 28 April. $20 \mathrm{pp}$.

Reynolds, W.D. 1976. Cave and Basin interpretive research. Unpubl. rept. prepared for the Director, Western Region, Parks Canada, Calgary, AB. 1 November. 53 pp.+appendices.

Richter, B.D., D.P. Braun, M.A. Mendelson, and L.L. Master. 1997. Threats to imperiled freshwater fauna. Cons. Biol. 11:10811093. 
Royal Canadian Mint. 2001. Products Circulation web site: URL: http://www.rcmint.ca/.

Sankurathri, C.S., and J.C. Holmes. 1976. Effects of thermal effluents on the population dynamics of Physa gyrina Say (Mollusca: Gastropoda) at Lake Wabamun, Alberta. Can. J. Zool. 54:582-590.

Satterly, J., and R.T. Elworthy. 1917. Mineral Springs of Canada. Part I. The radioactivity of some Canadian Mineral Springs. Department of Mines, Mines Branch, Canada, Report 435, Bulletin 16. $60 \mathrm{pp}$.

Scott, D., and R. Suffling. 2000. Climate change and Canada's national park system: a screening level assessment. Parks Canada, Ottawa, ON. 183 pp.

Seddon, M.B. 1998. Red listing of molluscs: a tool for conservation? In Molluscan conservation: a strategy for the $21^{\text {st }}$ century. J. Conch. Spec. Publ. 2:27-44.

Seddon, M.B., I.J. Killeen, P. Bouchet, and A.E. Bogan. 1998. Developing a strategy for molluscan conservation in the next century in Molluscan conservation: a strategy for the $21^{\text {st }}$ century. J. Conch. Spec. Publ. 2:295-298.

Souther, J.G., and E.C. Halstead. 1973. Mineral and thermal waters of Canada. Geol. Surv. Can. Paper 73-18.

Swales, W.E. 1935. The life cycle of Fascioloides magna (Bassi, 1875), the large liver fluke of ruminants, in Canada. Can. J. Res., Sect. D 12:177-215.

Te, G.A. 1978. A systematic study of the Family Physidae (Basommatophora: Pulmonata). Ph.D. Thesis. University of Michigan, Ann Arbour, MI. 324 pp. [Available through University Microfilms International, Ann Arbor, MI, 48106].

Te, G.A. and A.H. Clarke. 1985. Physella (Physella) wrighti (Gastropoda: Physidae), a new species of tadpole snail from Laird Hot Springs, British Columbia. Can. Field-Nat. 99:295-299.

Van Everdingen, R.O. 1970. Seasonal variations, Sulphur Mountain hot springs, Banff, Alberta. Inland Waters Branch, Department of Energy, Mines and Resources. Tech. Bull. 33:1-11.

Van Everdingen, R.O. 1972. Thermal and mineral springs in the southern Rocky Mountains of Canada. Water Management Service, Department of the Environment, Ottawa, ON. 151 pp.

Van Everdingen, R.O. 1991. Physical, chemical, and distributional aspects of Canadian springs. Mem. Entomol. Soc. Can. 155:7-28.

Van Everdingen, R.O., and J.A. Banner. 1982. The Cave-and-Basin Spring Area, Banff National Park, Alberta - Geohydrologic, geochemical, geothermal, and environmental considerations for the development of the Cave-and-Basin Centennial Centre. National Hydrology Research Institute, Environment Canada, Calgary, AB. 42 pp. + tables and figures.

Warren, P.S. 1927. Banff area, Alberta. Geol. Surv. Can. Mem. 153, No. 134, Geol. Ser. 94 pp.

Wells, S.M. 1995. Molluscs and the conservation of biodiversity. Pp. 21-36 in Biodiversity and conservation of the Mollusca (A.C. van Bruggen, S.M. Wells, and Th.C.M. Kemperman, eds.). 
Proceedings of the Alan Solem Memorial Symposium on the biodiversity and conservation of the Mollusca at the $11^{\text {th }}$ International Malacological Congress, Siena, Italy, 1992. Backhuys Publishers, the Netherlands.

Wells, S.M., and J.E. Chatfield. 1995. Conservation priorities for European non-marine molluscs. Pp. 133-152 in Biodiversity and conservation of the Mollusca (A.C. van Bruggen, S.M. Wells, and Th.C.M. Kemperman, eds.). Proceedings of the Alan Solem Memorial Symposium on the biodiversity and conservation of the Mollusca at the $11^{\text {th }}$ International Malacological Congress,
Siena, Italy, 1992. Backhuys Publishers, the Netherlands.

Woodsworth, G. 1999. Hot springs of western Canada. $2^{\text {nd }}$ edition. Gordon Soules Book Publishers Ltd., West Vancouver, BC. $288 \mathrm{pp}$.

Wu, S.-K. 1989. Natural history inventory of Colorado, No. 11. Colorado freshwater molluscs. Univ. Colorado Mus., Boulder, CO. $117 \mathrm{pp}$.

Wu, S.-K., and D.E. Beetle. 1995. Wyoming Physidae (Gastropoda: Pulmonata: Hygrophila). Malacol. Rev. 28:81-95. 
APPENDIX 1. Definitions of selected legal and protective designations.

A. The General Status of Alberta Wild Species 2000 (after Alberta Sustainable Resource Development 2001)

\begin{tabular}{|l|l|l|}
\hline 2000 Rank & 1996 Rank & Definitions \\
\hline At Risk & Red & $\begin{array}{l}\text { Any species known to be at risk after formal assessment and } \\
\text { designation as Endangered or Threatened in Alberta. }\end{array}$ \\
\hline May Be At Risk & Blue & $\begin{array}{l}\text { Any species believed to be at risk. These species will require a } \\
\text { detailed assessment for possible formal designation as Endangered } \\
\text { or Vulnerable. }\end{array}$ \\
\hline Sensitive & Yellow & $\begin{array}{l}\text { Any species known to be, or believed to be, particularly sensitive } \\
\text { to human activities or natural events. }\end{array}$ \\
\hline Secure & Green & Any species known to be, or believed to be, not at risk. \\
\hline Undetermined & $\begin{array}{l}\text { Status } \\
\text { Undetermined }\end{array}$ & $\begin{array}{l}\text { Any species where not enough information exists to adequately } \\
\text { use the ranking system (exceptional cases only). }\end{array}$ \\
\hline Not Assessed & n/a & $\begin{array}{l}\text { Any species known or believed to be present but which have not } \\
\text { yet been evaluated. }\end{array}$ \\
\hline Exotic/Alien & n/a & $\begin{array}{l}\text { Any species that have been introduced as a result of human } \\
\text { activity. }\end{array}$ \\
\hline Extirpated/Extinct & n/a & $\begin{array}{l}\text { Any species no longer thought to be present in the jurisdiction or } \\
\text { are believed to be extinct. }\end{array}$ \\
\hline Accidental/Vagrant & n/a & $\begin{array}{l}\text { Any species occurring infrequently and unpredictably outside their } \\
\text { usual range. }\end{array}$ \\
\hline
\end{tabular}

\section{B. Alberta's Wildlife Act}

Species designated as "Endangered" under Alberta's Wildlife Act include those defined as "Endangered" or "Threatened" by A Policy for the Management of Threatened Wildlife in Alberta (Alberta Fish and Wildlife 1985):

\begin{tabular}{|l|l|}
\hline Endangered & $\begin{array}{l}\text { A species whose present existence in Alberta is in danger of extinction within the next } \\
\text { decade. }\end{array}$ \\
\hline Threatened & $\begin{array}{l}\text { A species that is likely to become endangered if the factors causing its vulnerability are } \\
\text { not reversed. }\end{array}$ \\
\hline
\end{tabular}

\section{Committee on the Status of Endangered Wildlife in Canada (after COSEWIC 2002)}

\begin{tabular}{|l|l|}
\hline Extinct & A species that no longer exists. \\
\hline Extirpated & A species that no longer exists in the wild in Canada, but occurs elsewhere. \\
\hline Endangered & A species facing imminent extirpation or extinction. \\
\hline Threatened & A species that is likely to become endangered if limiting factors are not reversed. \\
\hline Special Concern & $\begin{array}{l}\text { A species of special concern because of characteristics that make it particularly } \\
\text { sensitive to human activities or natural events. }\end{array}$ \\
\hline Not at Risk & A species that has been evaluated and found to be not at risk. \\
\hline Data Deficient & $\begin{array}{l}\text { A species for which there is insufficient scientific information to support status } \\
\text { designation. }\end{array}$ \\
\hline
\end{tabular}




\begin{tabular}{|c|c|}
\hline $\begin{array}{l}\text { G1/N1/ } \\
\text { S1 }\end{array}$ & $\begin{array}{l}\text { Critically Imperiled: Critically imperiled globally because of extreme rarity or because of } \\
\text { some factor(s) making it especially vulnerable to extinction. Typically } 5 \text { or fewer occurrences } \\
\text { or very few remaining individuals }(<1,000) \text { or acres }(<2,000) \text { or linear miles }(<10) \text {. }\end{array}$ \\
\hline $\begin{array}{l}\text { G2/N2/ } \\
\text { S2 }\end{array}$ & $\begin{array}{l}\text { Imperiled: Imperiled globally because of rarity or because of some factor(s) making it very } \\
\text { vulnerable to extinction or elimination. Typically } 6 \text { to } 20 \text { occurrences or few remaining } \\
\text { individuals }(1,000 \text { to } 3,000) \text { or acres }(2,000 \text { to } 10,000) \text { or linear miles }(10 \text { to } 50) \text {. }\end{array}$ \\
\hline $\begin{array}{l}\text { G3/N3/ } \\
\text { S3 }\end{array}$ & $\begin{array}{l}\text { Vulnerable: Vulnerable globally either because very rare and local throughout its range, found } \\
\text { only in a restricted range (even if abundant at some locations), or because of other factors } \\
\text { making it vulnerable to extinction or elimination. Typically } 21 \text { to } 100 \text { occurrences or between } \\
3,000 \text { and } 10,000 \text { individuals. }\end{array}$ \\
\hline $\begin{array}{l}\text { G4/N4/ } \\
\text { S4 }\end{array}$ & $\begin{array}{l}\text { Apparently Secure: Uncommon but not rare (although it may be rare in parts of its range, } \\
\text { particularly on the periphery), and usually widespread. Apparently not vulnerable in most of its } \\
\text { range, but possibly cause for long-term concern. Typically more than } 100 \text { occurrences and more } \\
\text { than } 10,000 \text { individuals. }\end{array}$ \\
\hline $\begin{array}{l}\text { G5/N5/ } \\
\text { S5 }\end{array}$ & $\begin{array}{l}\text { Secure: Common, widespread, and abundant (although it may be rare in parts of its range, } \\
\text { particularly on the periphery). Not vulnerable in most of its range. Typically with considerably } \\
\text { more than } 100 \text { occurrences and more than } 10,000 \text { individuals. }\end{array}$ \\
\hline $\begin{array}{l}\text { GX/NX/ } \\
\text { SX }\end{array}$ & $\begin{array}{l}\text { Presumed Extinct (species) - Believed to be extinct throughout its range. Not located despite } \\
\text { intensive searches of historical sites and other appropriate habitat, and virtually no likelihood } \\
\text { that it will be rediscovered. } \\
\text { Eliminated (ecological communities) - Eliminated throughout its range, with no restoration } \\
\text { potential due to extinction of dominant or characteristic species. }\end{array}$ \\
\hline $\begin{array}{l}\text { GH/NH/ } \\
\text { SH }\end{array}$ & $\begin{array}{l}\text { Possibly Extinct (species) - Known from only historical occurrences, but may nevertheless still } \\
\text { be extant; further searching needed. } \\
\text { Presumed Eliminated (Historic, ecological communities) - Presumed eliminated throughout its } \\
\text { range, with no or virtually no likelihood that it will be rediscovered, but with the potential for } \\
\text { restoration, for example, American Chestnut (Forest). }\end{array}$ \\
\hline
\end{tabular}

\section{E. United States Endangered Species Act (after National Research Council 1995)}

\begin{tabular}{|l|l|}
\hline Endangered & $\begin{array}{l}\text { Any species which is in danger of extinction throughout all or a significant portion of } \\
\text { its range. }\end{array}$ \\
\hline Threatened & $\begin{array}{l}\text { Any species which is likely to become an endangered species within the foreseeable } \\
\text { future throughout all or a significant portion of its range. }\end{array}$ \\
\hline
\end{tabular}




\section{List of Titles in This Series}

(as of March 2002)

No. 1 Status of the Piping Plover (Charadrius melodus) in Alberta, by David R. C. Prescott. 19 pp. (1997)

No. 2 Status of the Wolverine (Gulo gulo) in Alberta, by Stephen Petersen. 17 pp. (1997)

No. 3 Status of the Northern Long-eared Bat (Myotis septentrionalis) in Alberta, by M. Carolina Caceres and M. J. Pybus. 19 pp. (1997)

No. 4 Status of the Ord's Kangaroo Rat (Dipodomys ordii) in Alberta, by David L. Gummer. 16 pp. (1997)

No. 5 Status of the Eastern Short-horned Lizard (Phrynosoma douglassii brevirostre) in Alberta, by Janice D. James, Anthony P. Russell and G. Lawrence Powell. 20 pp. (1997)

No. 6 Status of the Prairie Rattlesnake (Crotalus viridis viridis) in Alberta, by Sheri M. Watson and Anthony P. Russell. 26 pp. (1997)

No. 7 Status of the Swift Fox (Vulpes velox) in Alberta, by Susan E. Cotterill. 17 pp. (1997)

No. 8 Status of the Peregrine Falcon (Falco peregrinus anatum) in Alberta, by Petra Rowell and David P. Stepnisky. 23 pp. (1997)

No.9 Status of the Northern Leopard Frog (Rana pipiens) in Alberta, by Greg Wagner. 46 pp. (1997)

No. 10 Status of the Sprague's Pipit (Anthus spragueii) in Alberta, by David R. C. Prescott. 14 pp. (1997)

No. 11 Status of the Burrowing Owl (Speotyto cunicularia hypugaea) in Alberta, by Troy I. Wellicome. 21 pp. (1997)

No. 12 Status of the Canadian Toad (Bufo hemiophrys) in Alberta, by Ian M. Hamilton, Joann L. Skilnick, Howard Troughton, Anthony P. Russell, and G. Lawrence Powell. 30 pp. (1998)

No. 13 Status of the Sage Grouse (Centrocercus urophasianus urophasianus) in Alberta, by Cameron L. Aldridge. 23 pp. (1998)

No. 14 Status of the Great Plains Toad (Bufo cognatus) in Alberta, by Janice D. James. 26 pp. (1998)

No. 15 Status of the Plains Hognose Snake (Heterodon nasicus nasicus) in Alberta, by Jonathan Wright and Andrew Didiuk. 26 pp. (1998)

No. 16 Status of the Long-billed Curlew (Numenius americanus) in Alberta, by Dorothy P. Hill. 20 pp. (1998)

No. 17 Status of the Columbia Spotted Frog (Rana luteiventris) in Alberta, by Janice D. James. 21 pp. (1998)

No. 18 Status of the Ferruginous Hawk (Buteo regalis) in Alberta, by Josef K. Schmutz. 18 pp. (1999)

No. 19 Status of the Red-tailed Chipmunk (Tamias ruficaudus) in Alberta, by Ron Bennett. 15 pp. (1999)

No. 20 Status of the Northern Pygmy Owl (Glaucidium gnoma californicum) in Alberta, by Kevin C. Hannah. 20 pp. (1999)

No. 21 Status of the Western Blue Flag (Iris missouriensis) in Alberta, by Joyce Gould. 22 pp. (1999)

No.22 Status of the Long-toed Salamander (Ambystoma macrodactylum) in Alberta, by Karen L. Graham and G. Lawrence Powell. 19 pp. (1999) 
No. 23 Status of the Black-throated Green Warbler (Dendroica virens) in Alberta, by Michael R. Norton. 24 pp. (1999)

No. 24 Status of the Loggerhead Shrike (Lanius ludovicianus) in Alberta, by David R. C. Prescott and Ronald R. Bjorge. 28 pp. (1999)

No. 25 Status of the Plains Spadefoot (Spea bombifrons) in Alberta, by Richard D. Lauzon. 17 pp. (1999)

No. 26 Status of the Trumpeter Swan (Cygnus buccinator) in Alberta, by M. Lynne James. 21 pp. (2000)

No.27 Status of the Pygmy Whitefish (Prosopium coulteri) in Alberta, by William C. Mackay. 16 pp. (2000)

No. 28 Status of the Short-eared Owl (Asio flammeus) in Alberta, by Kort M. Clayton. 15 pp. (2000)

No. 29 Status of the Willow Flycatcher (Empidonax traillii) in Alberta, by Bryan Kulba and W. Bruce McGillivray. 15 pp. (2001).

No. 30 Status of the Woodland Caribou (Rangifer tarandus caribou) in Alberta, by Elston Dzus. 47 pp. (2001)

No.31 Status of the Western Spiderwort (Tradescantia occidentalis) in Alberta, by Bonnie Smith. 12 pp. (2001)

No. 32 Status of the Bay-breasted Warbler (Dendroica castanea) in Alberta, by Michael Norton. 21 pp. (2001)

No. 33 Status of the Cape May Warbler (Dendroica tigrina) in Alberta, by Michael Norton. 20 pp. (2001)

No. 34 Status of the Whooping Crane (Grus americana) in Alberta, by Jennifer L. White. 21 pp. (2001)

No.35 Status of Soapweed (Yucca glauca) in Alberta, by Donna Hurlburt. 18 pp. (2001)

No. 36 Status of the Harlequin Duck (Histrionicus histrionicus) in Alberta, by Beth MacCallum. 38 pp. (2001)

No. 37 Status of the Grizzly Bear (Ursus arctos) in Alberta, by John L. Kansas. 43 pp. (2002)

No. 38 Status of the Wood Bison (Bison bison athabascae) in Alberta, by Jonathan A. Mitchell and C. Cormack Gates. 32 pp. (2002)

No. 39 Status of the Bull Trout (Salvelinus confluentus) in Alberta, by John R. Post and Fiona D. Johnston. 40 pp. (2002).

No. 40 Status of the Banff Springs Snail (Physella johnsoni) in Alberta, by Dwayne A.W. Lepitzki. 29 pp. 

National Library of Canada
Bibliothèque nationale du Canada

|||||||||||||||||||||||||||||||||||||||||||||||||||||||||||||||||||||||||||||||||||||||||||||||||||||||||||||||||||||||||||

33286527926469 